“Babies Aren’t Persons”: A Survey of Delayed Personhood

David F. Lancy ${ }^{1}$

Utah State University

Chapter to appear in 2013. Different Faces of Attachment: Cultural Variations of a Universal Human Need. Keller, Heidi and Otto, Hiltrud (Eds) Cambridge: Cambridge University Press.

\begin{abstract}
To better understand attachment from a cross-cultural and historical perspective, I have amassed over 200 cases from the ethnographic and archaeological records that reveal cultural models (D'Andrade and Strauss 1992) of infancy. The 200 cases represent all areas of the world, historical epochs from the Mesolithic to the present and all types of subsistence patterns (Appendix 1). The approach is inductive where cases with similar models of infancy are clustered into archetypes. My principal finding from this analysis is that, in the broadest overview, infants are, effectively, placed on probation and not immediately integrated into the society. Attachment failure is not seen as a potential problem but, rather, premature attachment to an infant whose existence may be fleeting is to be guarded against. Most societies view infants and even children as not-yet-persons. Infants are born into a state of liminality or incompleteness. Among the Wari, a baby is compared to unripe fruit as it is "still being made" (Conklin and Morgan 1996: 672) and the Nankani reserve judgment on the infant's humanity until they can be certain it is not a spirit or bush child (Denham et al 2010: 608). My presentation of results will first identify the main factors that give rise to delaying personhood and, second, to the cultural models which justify and guide the transformation of babies into persons. Variability in the way this non-personhood is characterized and in the steps that must occur to complete the process of constructing a person is great but not infinite. Hence, in the second half of the chapter, I will identify and discuss several archetypal cultural models of infancy.
\end{abstract}

\title{
Attachment and Attachment Parenting
}

In the middle of the last century, John Bowlby (1953), an English psychotherapist, advanced a set of ideas about the emotional ties between a mother and her infant and the deleterious effects of maternal deprivation. These propositions are now widely known as "attachment theory." A critical component of the theory was its universality; all mother-child dyads must engage in behaviors, which build and strengthen mutual bonds during a critical period from six-eighteen months. The theory has, since then, gathered adherents across a broad spectrum from developmental psychologists testing for evidence of "secure" versus "avoidant" or "ambivalent/resistant" attachment (Ainsworth, et al 1978) to social workers who point to attachment failure as the root of criminal behavior. Numerous empirical studies have extended attachment to non-industrialized societies with mixed results but, overall, they suggest considerable cross-cultural variability (Keller, 2007; van IJzendoorn and Sagi-Schwartz 2008; Tomlinson et al, 2010).

There has, nevertheless, been a steady escalation in the expectation for adequate parenting to prevent attachment failure (Karen 1998; Newton and Schore 2008). Recently, attachment theory can be regarded as having morphed into a kind of secular religion where mothers worship at the altar of "attachment parenting"." That is, among the social elite in the US, "attachment" has become synonymous with good, correct child rearing. This "movement" is supported by many quasi-scientific parenting volumes as well as by web-based organizations. The goal of Attachment.org is to provide help for "each wounded child with attachment disorder [which is caused by, for example] 'Caring for baby on a timed schedule or other self-centered parenting ${ }^{3}$."' Much of the advice-to-parents literature suggests that full-scale attachment parenting is supported by anthropological research (especially on topics like the frequency of nursing and physical contact between mother and infant) and is, therefore "natural." Failure to embrace the whole suite of prescribed parenting practices is, therefore, unnatural. One confirmed apostate in the new attachment parenting faith is noted US media personality Erica Jong. She characterizes attachment parenting as "You wear your baby, sleep with her and attune yourself totally to her needs [then wonders how one can] do this and also earn the money to keep her"." Another, more credible, dissenting perspective is provided by a study of attachment in Germany. In spite of the fact that, using standardized measures, "Two-thirds of the Bielfeld children were classified as "insecurely attached," the authors reject the possibility that these children are at risk of developing personality disorders (LeVine and Norman 2001: 97). And they suggest that the behavior of German mothers is guided by a cultural model of child development that cautions against excessive attention being paid to the infant: 
"They view the infant's needs for physical and social care as important but emphasize attention to satisfying those needs without disturbing family routines too much, and they are also concerned about the danger that a young child will become "spoiled," verwöhnt, by excessive attention and too much accommodation to its needs and demands (LeVine and Norman 2001: 91-2)."

\section{Attachment and Anthropology}

Anthropologists studying mother-infant relations provide ethnographic descriptions that don't square with "attachment parenting" orthodoxy. Researchers who have directly addressed attachment theory have expressed considerable skepticism towards the theory based on the evidence from their own ethnographic research, Alma Gottlieb's study of the Beng (1995), Nancy Scheper-Hughes' (1987) study of Alto do Cruzeiro and Bob LeVine's (2004) work with the Gusii are notable. As examples, consider the Kpelle in rural Liberia where babies experience "Casual nurturance by mothers who carry their babies on their backs and nurse them frequently but do so without really paying much direct attention to them; they continue working or... socializing (Erchak 1992: 50)." Paradise records that "When a [Mazahua] mother holds a nursing baby in her arms she frequently has a distracted air and pays almost no attention to the baby (1996: 382)." "Gusii mothers rarely looked at or spoke to their infants and toddlers, even when they were holding and breast-feeding them (LeVine 2004: 154)." In none of these cases did the anthropologists observe any decrement in the mental health of individuals subjected to - in attachment parenting orthodoxy - maternal deprivation.

These studies represent robust illustrations of what LeVine has called the "anthropologist's veto (2007: 250)." That is, anthropologists have a history of undermining the claims of universality made by developmental psychologists. Two further examples include the practice of talking to nonverbal infants using a special speech register (baby talk or motherese). Usually assumed to be both universal and essential to the development of speech in children, it is neither (Ochs and Schieffelin 1984). "Parenting style" theory (Baumrind 1971) cannot withstand cross-cultural scrutiny. Central African Bofi farmers fit the so-called authoritarian parenting style in valuing respect and obedience and exercising coercive control over their children. Bofi children should, according to theory, be withdrawn, nonempathetic, aggressive, and lack initiative. On the contrary, they display precisely the opposite traits, leading Fouts to conclude that the theory "has very little explanatory power among the Bofi (2005: 361)." More recently, Henrich and colleagues (2010) have crafted a sophisticated literature review illustrating the ethnocentric bias and distortion that is found in dominant research paradigms. Because of biased population samples and the inherent ethnocentrism of investigators, the views on child development found in the WEIRD (Western, Educated, Industrialized, Rich, and Democratic, cf, Henrich et al 2010) society are taken as the norm and, hence, nurture is turned into nature (Lancy 2010). A historical perspective on the same phenomenon argues "the attachment model of early child development belongs to the ideological camp of child-centered freedom and equality against old-fashioned parentally imposed order and discipline (LeVine and Norman 2001: 100).”

\section{Turning Attachment Parenting on its Head}

The basic argument underlying attachment theory is that each individual's mental health is at risk during the first two years of life. The child's psyche can be damaged if it is unable to establish a firm emotional tie to its mother (or appropriate substitute). The mother, in this theory, is expected to behave in ways that insure attachment (Bowlby 1953:11). In contemporary application of the theory (e.g. "attachment parenting"), the mother is challenged to take care of the infant's needs in a supportive and emotionally warm manner leading to a strong emotional bond. Among maternal behaviors commonly assumed to play a critical role in this process are: being available at all times to tend the infant; breastfeeding; holding the infant en face; speaking to it using baby talk or motherese; cuddling, kissing and otherwise demonstrating the strong positive affect the mother feels towards the infant and; playing with it. A mother's failure to actively promote her infant's emotional "high" leads to attachment failure, which leads to prison or worse.

From my survey of the literature on infancy outside contemporary bourgeois society, I can assert that the anthropological cases just mentioned are not atypical. The ethnographic record is quite consistent in showing mothers frequently nursing infants but, otherwise, paying them relatively little attention (Ainsworth 1967; ReichelDolmatoff 1976; Lancy 2007). Indeed, LeVine (2004) and others (True et al 2001) are probably correct in arguing that any baby that is - minimally — given regular and predictable nourishment while in close contact with another human being will be protected from the orphan warehouse syndrome or what Spitz (1945) called "hospitalism" and any lasting emotional damage. But I want to do more than pile on further cases that cast the theory of attachmentor at least the extreme position represented by the attachment parenting movement - into doubt. My goal here is to 
inductively construct a cultural model (D'Andrade and Strauss 1992) or models of infancy that help us to understand why the contemporary preoccupation with attachment has more to do with fashion than child welfare. The survey suggests not only a very "light" version of attachment parenting but that, in most societies, the greatest challenge facing families with newborns is to avoid forming a premature attachment. The infant's needs are obvious, less obvious are the needs of its mother and family and of the wider circumstances attendant on its birth. I identify the factors that may be present and that constitute the ecology of infancy. These factors all signal the need for caretakers to maintain a degree of emotional distance from the child. Six factors emerged from the survey, which militate against or temper the attention paid to infants. These are: high infant mortality and chronic illness; the mother's vulnerability; alloparenting and fostering; dysfunctional families; the infant is unwanted or on probation leading to neglect; abandonment and infanticide and; a utilitarian view of offspring. I take up each in turn.

\section{High Infant Mortality and Chronic Illness}

Infant mortality data are available for a range of societies from prehistoric settlements, nomadic foragers, farmers, and from complex societies in Europe and Asia. These data suggest that from one-fifth to one-half of babies don't make it to five years (Dentan 1978: 111; Kramer and Greaves 2007: 720; Lancy 2008: 55; Le Mort 2008: 25). We can extrapolate from these figures to conclude that miscarriages and stillbirths were also common by comparison to current levels. Likewise, we can expect that if half the children died then somewhat more than half were seriously ill in childhood. Indeed, in many villages studied by anthropologists the level of clinical malnutrition is 100 per cent, as is the level of chronic parasite infestation and diarrhea. There are, then, ample reasons for withholding investment in the infant and maintaining a degree of emotional distance.

"It was a Roman writer, Epictetus, who noted, "when you kiss your child, say to yourself, it may be dead in the morning (Stearns 2010: 168)."

"Childhood, according to the seventeenth-century French cleric Pierre de Bérulle, 'is the most vile and abject state of human nature, after that of death' (cited in Heywood 2001:9)."

"The infant mortality rate [among the Bajau] is extremely high, and it is not uncommon to encounter a family with more deceased than living children. In fact, infant mortality is so high that some parents cannot even recall the number of their deceased children." (Nimmo 1970: 261)."

"In the 1760's Lomonosov estimated that fully one-half of Russia's children died by the age of three (Dunn 1974: 385)."

Of 15,000 babies left at the Ospidale Innocenti between 1755 and 1773, two-thirds died before reaching their first birthday (Kertzer 1993: 299)

"The [Neolithic era] skeletal sample consists of 109 infants less than one year old, twenty-five juveniles, and 106 adults. ...the age distribution of juveniles... reveals a high proportion of infants less than one year old, most of them (ninety-one per cent) deceased perinatally (Le Mort 2008: 25)."

"The relatively low reproductive rates of hunter-gatherer populations have been attributed to high natural mortality, low fertility, and cultural practices such as infanticide and sexual abstention (Spielmann 1989: 321)."

These grim statistics provoke a "wait-and-see" attitude toward the newborn and the narratives or parental ethnotheories (Harkness and Super 1995) constructed about infancy reflect this uncertainty.

\section{The Mother's Vulnerability}

Another inexorable factor affecting the newborn is the threat it represents to its mother. Throughout much of human history, pregnancy was treated as a serious illness. Childbirth was, until recently, extremely risky and even if the mother survives she may become the target of jealousy and witchcraft on the part of human and non-human adversaries. She and the babe are both contaminated by the process of birth and the spilling of puerperal blood. Women are also made vulnerable by the need to obey food taboos at critical junctures such as menstruation and pregnancy. These taboos often involve restricting their intake of high quality fat and protein-rich foods (Spielmann 1989: 323). Most critical is the fact that the new mother is also likely: responsible for maintaining a household; caring for a husband, older children, parents or parents-in-law and making a major contribution to subsistence or the 
domestic economy through (for example) craftwork (Boserup 1970). The health and recovery of the mother is seen as far more urgent than the emotional health of the infant.

"Childbirth is by far the greatest peril faced by [Semai] women in their reproductive years, accounting for thirteen of twenty-nine deaths, (forty-five per cent), and half of all deaths from known causes (Dentan 1978: 111)."

“A pregnant woman has one foot in the grave' according to a proverb from Gascony (Heywood 2001: 58)."

"Pregnant [Masaai] women attempt to become as emaciated as possible in order that the birth may proceed more easily. During the last 3 or 4 months of pregnancy the woman abandons her normal diet and exists on a near starvation diet...The last month, she drinks only milk (De Vries 1987: 170).”

"A budda may "eat" the blood of the [Macha-Galla] child or the mother, causing illness or even death. A tolca may harm them by some malevolent action (Batels 1969: 408)."

"The [new Ladakh] mother is plied with foods [to] regain her strength. Her health is paramount- to care for the baby and to get back to the routine household and agricultural tasks upon which the success of the household depends - while household members simply hope for the best with regard to the newborn (Wiley 2004: 132)."

"Behavioral scan data also provide evidence for male dominance: women spent twenty-one per cent more time working than men... and men spent twenty-nine per cent more time resting than women (Strassmann 1997: 688)."

Given the threats to its survival and low value relative to the mother (and older, living siblings), it is not surprising that the infant is, at least initially, in a marginal state.

\section{Alloparenting and Fostering}

At the peak of her childbearing years the young mother is also a critical contributor to the household economy. Hence, most societies embrace alloparenting as the means to lighten the mother's burden and thereby increase her fertility and her productivity. In a comprehensive survey of the ethnographic record: "forty per cent of infants were rated as being cared for by others... or cared for more than half the time by others. After infancy...less than twenty per cent of the societies had mothers as principal caretakers (Weisner and Gallimore 1977: 170)." Numerous studies underscore that infants are tended as often by a grandmother or older sibling as by the mother (Hrdy 1999). Further the widespread prevalence of wet-nursing (Sussman 1982), adoption and fostering (Alexandre-Bidon and Lett 1999: 54) and, less commonly, the sale of infants (MacGinnis 2011) suggests that the bond between mother and child should be, preferentially, weak.

"Despite the fact that Aka [forager] and Ngandu [farmer] mothers carry their infants with them during subsistence activities, the frequency of maternal caregiving and maternal intimacy is negatively associated with work activities... when high-quality allomaternal care is available, Aka mothers reduce caregiving and spend more time in subsistence-economic activities (Meehan 2009: 389)."

"While awake, Hausa infants are almost always in close physical proximity to one or more adult caregivers...infant signals, such as crying, are responded to promptly by adults or older children...Although Hausa infants app ear to be attached to three or four different figures (including fathers), most are primarily attached to one. Importantly, the principal figure is not necessarily the mother, who is solely responsible for feeding, but rather the person who holds and otherwise interacts with the infant the most (Tomlinson et al 2010: 185)."

"[Beng mothers have several strategies] to bind the infant to potential caretakers. When a visitor calls, the baby is to be awakened and displayed proudly...'You want to teach your baby how to be sociable, too, and to get to know all her relatives... make sure the baby looks beautiful! Every morning after you give the baby her bath, make sure you put herbal makeup on her face...the baby will be so irresistibly beautiful that someone will feel compelled to carry her around for a while that day' (Gottlieb 1995: 23-4)."

"There are numerous taboos and rules of avoidance between [Baatombu] biological parents and children [who've been given in adoption]. They are forbidden to call the children by their first name. Instead, they have 
to use nicknames or paraphrases. Even in the first hours after birth I observed mothers expressing distance towards their newborn child in the presence of a watching crowd of friends and relatives (Alber 2004: 40)."

To the extent that attachment theory focuses attention on the mother's behavior, we can see that her responsibilities as caretaker may be attenuated by cultural patterns that elevate other aspects of her multi-faceted role and that cast others in the role of caretaker. If the child has not already been under the care of others, certainly at weaning it will be. "Toddler rejection" (Weisner and Gallimore 1977: 176) is a widely reported phenomenon in which the infant is weaned early (by its lights), separated from its (likely pregnant) mother, placed in the care of a grandmother or sibcaretakers and, generally, ignored (Lancy and Grove 2010: 148-9).

\section{Dysfunctional Families}

The flip side of the alloparenting, "It Takes a Village" childcare pattern is that, in some societies ${ }^{5}$, strife within the extended family is endemic - leading to chronically dysfunctional families. By dysfunctional, I mean that strife between the generations, between spouses and between co-wives is so common it is expected. Indeed, conflict is so much a part of daily life, it is reflected in the cultural model of infancy. The Dogon case has been most thoroughly studied and reflects the rivalry that may exist among unrelated co-wives ${ }^{6}$. Other examples of the child being the center of rivalry among women from West Africa follow.

"The indigenous Dogon explanation is that poor survivorship under polygyny reflects competition among cowives. Cowives are not related, and the rivalry among them extends to their sons, who, upon the death of their father, almost invariably stop farming together...it was widely assumed that cowives often fatally poisoned each other's children. I witnessed special masked dance rituals intended by husbands to deter this behavior. Cowife aggression is documented in Malian court cases with confessions and convictions for poisoning. These cases raise the possibility that Dogon sorcery might have a measurable demographic impacta view that is consistent with the extraordinarily high mortality of males compared with females. Males are said to be the preferred targets because daughters marry out of the patrilineage whereas sons remain to compete for land. Even if women do not poison each other's children, widespread hostility of the mother's cowife must be a source of stress (Strassmann 1997: 693)."

"Sorcery is considered to be the most important reason for a [Papel] child's death. It is seen as a serious...problem. Because of envy, hatred, vindictiveness, or simply bad intentions some people decide to use sorcery to hurt a rival or someone they dislike. A child is often the chosen victim (Einarsdottir 2004: 116-17)."

"[Hausa] babies can be stolen by witches or child-seeking spirits. To avoid the attention of these entities, it is best not to openly praise children. 'Rolling your child in cow dung is also a good way to fool greedy spirits into thinking that your child is not worth taking. Occasionally, remark to a friend, 'Have you ever seen such an ugly baby?' (Johnson 2000: 187)."

The source of conflict may be the adulterous liaisons of a parent. "Divorce and remarriage...increase a child's risk of dying (Sear and Mace 2008: 9)" and children exposed to inter-parental conflict show heightened levels of cortisol and long-term negative health outcomes (Flinn and England 2002).

"[phiringaniso is an] illness attributed to violation of the norms of sexual behavior by a [Tsonga] parent of the sick child. It is usually provoked by a man's having extramarital intercourse while his child is still breastfeeding... The child becomes 'contaminated' and soon after exhibits watery diarrhea. The mother might also cause this diarrhea in her child by having 'outside' sexual relations (Green et al 1994: 11).”

"A woman in San Gabriel sometimes said that her second child had died of colerin, caused by drinking her breast milk when she was consumed by jealousy, rage, and pain from learning that her husband was having an affair. Colerin is incurable; it strikes and kills vulnerable infants quickly and surely. Children are thus killed by their fathers' selfish, irresponsible actions, which poison their mothers' milk (Morgan 1998: 70)."

The conflict could arise from the jealousy of an older sibling who's been (or about to be) displaced from the breast or the mother's full attention.

"If [an Ijaw] woman with a living child has experienced one or more unsuccessful pregnancies, or if she has not app arently conceived for a long period after having a child, a diviner might tell her that the living child wishes to be the last child, that it wants no younger rivals, and that it is killing her unborn babies (Leis 1982: 163)." 
In at least some societies, conflict within the family is endemic or to-be-expected. Under these circumstances, the threats to the child's survival are magnified, casting in shadow any concerns over attachment and the child's longterm emotional health. On the contrary, conspicuous displays of affection or emotional bonding could attract the attention of harmful forces or individuals.

\section{Infant Unwanted or On Probation Leading to Neglect, Abandonment and Infanticide}

Only a tiny fraction of the world's societies have accorded an unconditional welcome to every new member (Meskell 1994: 39). In societies where well-formed, full-term newborns may not survive to become helpful and able to pay back the investment made in them, the actuarial odds dictate a very careful evaluation of the newborn. Is it completely whole? Does it behave normally, crying neither too little nor too much? Is it a girl when a boy is infinitely preferred? Did it arrive "too soon" before its older and, hence more valuable sibling had been weaned? Is it unquestionably the offspring of its mother's husband (Schiefenhovel 1989)? Does the mother have a husband?

"Illegitimate [Mundurucu] children are usually killed at birth, along with twins and children with birth defects. If the child does survive it is referred to as "tun" which means excrement. They are not abused, but they cannot marry due to their indefinite status (Murphy and Murphy 1985: 127)."

"It was an ironclad rule that no [Tapirapé] woman should have more than three living children...A fourth child, or a third child if it were of the wrong sex, was buried immediately after its birth...'We do not want to see hunger in their eyes.' They pointed out to me the difficulty of providing food, especially meat, for more than three children (Wagley 1977: 135)."

"Children delivered in breech births were sometimes exposed. In a Han-dynasty lexicon, the word for breech is equated with $(w u)$, meaning 'obstinate,' disobedient, or unfilial. Thus it is possible that the child's ability to physically torment its mother on its first day of life may have been interpreted as foreshadowing its future unfilial behavior (Kinney 1995: 25)."

"The Bakairí selectively practice infanticide...Most of such cases occur when the mother is still nursing an older infant and cannot properly care for another baby (Picchi 2000: 64).”

"You take them out into the bush and you leave them...they turn into snakes and slither away...You go back the next day, and they aren't there. Then you know for a sure that they weren't really [Dogon] children at all, but evil spirits (Dettwyler 1994: 85-86)."

"Among the Songye, those defined as "bad" or "faulty" children, including albino, dwarf, and hydrocephalic children, are considered supernaturals who have been in contact with sorcerers in the anti-world; they are not believed to be human beings, and they are expected to die (Devleiger 1995: 96)."

Previous surveys of the ethnographic and historic records affirm that the elimination of infants, via abortion (Devereux 1955) and infanticide (Daly and Wilson 1984) is nearly a cultural universal. Dickeman claims that "This capacity for selective removal in response to qualities both of offspring and of ecological and social environments may well be a significant part of the biobehavioral definition of Homo sapiens (Dickeman 1975: 108) Again, the reasons for "not becoming too attached" predominate.

\section{Utilitarian View of Offspring}

The society that spawned and embraces attachment parenting is, comparatively, wealthy, well educated and enjoys both low infant and maternal mortality and a low birth rate. As documented in the Value of Children (VOC) surveys, there has been an ongoing transition - driven by economic development-from valuing children for their economic contributions to valuing them for the psychological rewards they bestow (Kagitcibasi and Ataca 2005: 318; see also Zelizer 1985). Theoretically, each newborn is/was subjected to a cost/benefit calculation (Trivers 1972). The costs are considered to be high, even for wanted, healthy offspring while the benefits lie in the future. In many societies, it is not until middle childhood that the individual can make a significant contribution to the household economy and is "noticed" (Lancy and Grove 2011a). Individual Infants are devalued if they are unlikely to provide a future return on the investment that will, perforce, be made in them. 
"In [the Beng] language, one word for 'child' really means 'little slave.' As soon as the little one can walk confidently, don't hesitate to send your child on errands in your village or neighborhood (Gottlieb 2000: 87)."

"A [n Amish] baby is never spoken of as "a little stranger" but is welcomed as a "new woodchopper" or a "little dishwasher (Hostetler and Huntington 1971: 22)."

"In the Chinese language, 'good' children are literally contrasted with 'useless' or 'unusable' children (Wee 1992: 192-193)."

"In Salic law [of the six-century C.E.]...one who killed a free young woman of childbearing age had to pay 600 sous, ... it is astonishing how small a case is made for the newborn, since the one who killed a male baby only had to pay sixty sous (thirty sous if it was a girl) (Alexandre-Bidon and Lett 1999: 13)."

I have earlier contrasted our culture as a neontocracy where infants are treated as cherubs with the rest of the premodern world exhibiting characteristics of a gerontocracy where children are viewed as chattel (Lancy 2008: 13, 256). This contrast allows us to see that the culture that gave birth to "attachment parenting" is rather unique in human annals. Most humans would ask why we should be excessively concerned about the feelings of an individual of such low value/status?

\section{Delayed Personhood}

Although I have argued that there are at least six overarching issues militating against attachment, these constitute only the raw material from which cultural models can be constructed. These raw facts serve as the foundation for culturally constituted theories of child development. The single most common element in non-western cultural models of infancy is delayed recognition of the infant's personhood or humanity. By treating infants as existing in a liminal state and not fully human, the community erects a large shelter or cognitive comfort zone within which several problems can be worked out. Firstly, infants really are different. Contemporary bourgeois society, almost uniquely, has chosen to construe those differences in a positive way (Lancy 2008: 77-80). Gurgling and babbling are evidence of cuteness not limited mental capacity. Because we enjoy the luxury of diapers, fresh water from a faucet, soap and lotions our babies smell sweet not poopy. Our mothers can take pleasure in playing peek-a-boo with their baby rather than having to lug it like a heavy book bag for miles to and from the garden. If one is not inclined to view the baby as an adorable cherub, then many infant characteristics such as the lack of speech, its softness, lack of motor control, crying and screaming, constant runny nose, diarrhea, lack of teeth/hair and mobility might be seen as anomalous, bestial or frightening. The Lepcha (among others,) think of the infant as still being in the womb (Gorer 1938: 209) not yet fully born. Indeed, most societies subscribe to some version of the idea that the infant is not just a really pathetic human being, it isn't a human being. Nor is it clear at the outset that it will necessarily become human, perhaps it's just a messenger or a vehicle being used by supernaturals.

"A decision had to be made within four days after parturition, for by that time an [Inuit] infant had to be named. And, once named, the disposal of a child would be an act of murder because a named infant was regarded as a social person (Balikci, 1970: 148)."

"During this period no one is very certain whether the [Ashanti] infant is going to turn out a human child or prove, by dying before this period has elapsed, that it was never anything more than some wandering ghost (Rattray 1927: 187)."

"Two [Fulani] folk illnesses regarded as supernaturally caused, foondu and heendu were important final diagnoses of the cause of death [which, when applied] to a dead child's last illness shifts accountability for the death to the community as a whole, rather than leaving the individual mother personally responsible (Castle 1994: 330)."

"The dead child is thought to have been the soul of someone to whom the [Hong Kong] parents owed a debt. When the debt is paid in terms of care invested in the child, it dies (Martin 2001: 162)."

Delayed personhood can serve as a firm foundation for building cultural models of infancy that are responsive to the six issues noted earlier. For example, infanticide is excused on the basis that one is not disposing of a person. Chronic illness and failure to thrive can be explained away as the failure of body and spirit to fuse, with the spirit 
drawn back to the other world (Teixeira 2007). Infants still have one foot in the spirit world, which renders them vulnerable to supernatural forces.

\section{Cultural Models of Infancy: The 'Not Yet Ripe' Model}

The delay in conferring personhood or outright denial serves as explicit or implicit foundation for several overarching cultural models of infancy. These models share one characteristic: most societies place the infant in a dynamic between two poles, expressed by concepts like hard versus soft. The infant's movement between these poles is closely monitored and carefully orchestrated.

We start with the "Not Yet Ripe" model. The denial of personhood is based on the patent deficiencies of the infant as a social being. Various attributes are singled out including, for example, the infant's softness and lack of motor control. Significantly, these models are used both to explain the basis of non-personhood but also include prescriptions for turning the baby into a person (Bonnet 2007), they have "directive force" (Harkness et al 1992). For example, the extremely widespread use of swaddling or cradleboard to restrain the infant is seen as compensating for and minimizing the long-term effects of the infant's softness and lack of motor control.

"[Navajo] babies are kept ... in the cradle to make them straight and strong. Some women let their children lie on sheepskins and roll about, but they are always weak, sick children (Leighton and Kluckhohn 1948: 23)."

“Asked why infants are swaddled, [Nurzay] women explained that the newborn baby's flesh is oma (lit. unripe) like uncooked meat, and that only by swaddling will it become strong (chakahosi) and solid like cooked (pokh) meat (Casimir 2010: 16)."

"Food taboos are aimed at 'hardening' the [baby's] body... The goal is to make the baby vigorous and strong, so it can grow fast and develop into an independent member of the longhouse. [Huaorani] men I interviewed insisted that both parents were... assisting in its fast growth through [their] fasting (Rival 1998: 623)."

"New-born [Amele] infants (momodo) are cold and soft...and must be strengthened by the application of warm hands heated over a fire. Only liquids, preferably lukewarm, may be given to momodo. As strength develops and the infant can hold up its head, it is known as momo memen, literally 'infant becomes stone' (Jenkins et al 1985: 39)."

" ....among the Bororo...the naming process takes place only when it is detected that the baby is 'hardened' enough (usually some five-six months after birth). It is only through the naming ceremony that the child becomes 'socially born' and recognized (Fabian, 1992: 66)."

Other areas singled out as needing ripening to transform the infant into a human being are speech (Bird-David 2005; 97; Kleijueqgt 2009: 55), self-locomotion (Bugos and McCarthy 1984: 510; Remorini 2011), acquisition of social knowledge and skill (Montague 1985: 89; Musharbash 2011; 66) and intelligence (Geertz 1961:105; Riesman 1992: 130; Woolf 1997: 71).

"But not until the kulio (from kungh + li, lit: head shaving), on the eighth day after birth, does the [Mandinka] infant move into the status of a fully recognized member of the family (Whittemore 1989: 87)."

"A [Ovimbundu] baby is born pink and it is only when he turns dark at the sixth or eighth day that he shows the first indication of becoming a person (отипи). He shows further promise in that direction with his first show of sense, but all through childhood he is, in a sense, only a potential person (Childs 1949: 120-1).”

"Before children can be treated...as individual persons or 'selves', they have to become Ambonwari...the main concern of initiation is to bring a 'non-being' into Ambonwari being...Until boys are initiated at six or seven, they are "not Ambonwari' (Telban 1997: 316)."

"For a [Gusii] mother to engage a small child, let alone an infant, 'in conversation' would...seem eccentric behavior...since.... child is not a valid human being until he reaches the age of 'sense' ... six or seven years old...(LeVine and LeVine 1981: 43-4).”

"There seem to be progressive phases of recognition of the [Bariba] child as a permanent member of society, key among which is the appearance of teeth. Both mothers and fathers state that they await the app earance of 
teeth anxiously to determine the future of the child and, in fact, to identify the child's essence-human or witch substance (Sargent 1988: 82)."

Interestingly, there is relatively little consensus in the "Not-Yet-Ripe" model or the remaining two to be discussed ("Unconnected" and "Two Worlds") regarding the age at which personhood is achieved. In fact, of 200 cases in which there is an evident delay in granting personhood, only in forty-three has the investigator indicated a likely stage or transition point after which personhood is acknowledged. Of these, in roughly fifteen the point falls within the first year with a second cluster (sixteen) at ages five-nine-the age of "sense."

\section{Cultural Models of Infancy: The 'Unconnected’ Model}

A second, but obviously parallel, model highlights the view that an infant, because it is kept in seclusion or largely hidden in the voluminous layers of its mother's clothing (Tronick et al 1994) is still in a womb-like state (Cerulli 1959: 25). To become fully human, the infant must exit from this metaphorical womb and enjoy a second birth where it is joined to its father, his clan and extended family (Blanchy 2007). To achieve this requires survival and maturation on the part of the newborn but, as well, various rites of separation and attachment are mandated. Soninké rites of separation involve proper treatment of umbilical cord and placenta while attachment rites include a ceremony with singing by a Griot, the exchange of gifts and acknowledgement of the child by ritual leaders (Razy 2007).

"For the first three days of life the [Lepcha] baby is considered to be still in the womb and all the pre-natal precautions have to be observed. It is not even referred to as a human child; it is called a rat-child (Gorer 1938: 289).”

"The new-born [Vlach] child sleeps tightly swaddled in a wooden rocking cradle which is enveloped from end to end in a blanket, so that he lies in a kind of dark airless tent (Campbell 1964: 154)."

"The post-partum [Japanese] child remains, inseparably a part of its mother. The infant continues to develop within the protective, womb-like environment of its mother's presence, excluding others (Lebra 1994: 261)."

"In a sense, a [Tamang] baby enters the world without a clan since it can only become part of the partriline after three days; to underscore this, male members of the household usually remain away from the child (Fricke 1994: 133)."

"Many...post-natal practices [involve the] gradual shedding of the symbols for maternal ties, e.g. for a [Hubeer] child that has not yet passed through the first ceremonies (e.g. the banaan bixin) that declare his agnatic links, it can be said that 'his bones are not yet hard' (Helander 1988: 150)."

This set of cases suggest that social attachment, including attachment to collectives like the extended family and clan, is of far more importance in cultural models of human development than psychological attachment.

\section{Cultural Models of Infancy: The 'Two Worlds' Model}

In a strict statistical sense, the most common rationale for withholding personhood is that the infant itself has not yet committed to being human. It is suspended between two worlds, the human world and the "other" world of spirits, ghosts, ancestors and, gods. There are several variations on this part-spirit/part-human theme, including characterizations of the child that emphasize its purity and innocence (Little Angels below), other views that see the child as a conduit of evil forces (Little Devils below) and, lastly the notion that the sprit child has no intention of becoming fully human (Tricksters, below). First, I will discuss cases where there is a distinct tension between the spirit or soul and the body.

"Having just come out of the Dreaming, the soul or spirit (kurunpa) of Anangu infants is still closely linked up and in communication with the Ancestors (Eickelkamp 2011: 109)."

"When the [Azande] child is born the soul has not become completely and permanently attached to its abode. Hence it is feared that the soul may flit away and this is one of the reasons for confining infant and mother to a hut for several days after birth lest 'The child's soul might get lost' (Evans-Pritchard 1932: 404)." 
"The perceived relationship of [Mende] infants with the world of spirits, generates loyalties in conflict with the world of the living....infants are presumed to develop unusual powers of vision and the powers to move across different sensory domains (Fermé 2001: 198)".

"Once people die, their souls... are said to become...spirits, that travel to wrugbe, the land of the dead....Eventually, the ancestors are reincarnated into this life. All newborns are seen as having just emerged from wrugbe [but if they die they're seen as still residing there] sometimes their ancestral identities are revealed early in childhood (Gottlieb 2000: 59)."

"A newborn [Yukui] has been contaminated by [puerperal] blood and is also more likely to succumb to disease or birth defects during these first few weeks of life. The baby was therefore regarded as not yet belonging fully to the world but lay somewhere between the spirit domain and that of the living (Stearman 1989: 89)."

In the following section, I will discuss the practices that are followed in order to insure that the child's spirit and body are permanently joined.

\section{Uniting Spirit and Body}

The "Two Worlds" cultural model not only explains observed phenomena but also prescribes actions to be taken by the infant's caretakers. Among the Nzebi in Gabon, twins are seen as spirits who chose to live among humans. It is important not to offend them so they do not engage in reprisals, such as the communication of various diseases and bad dreams or to simply return to where they came from. Ritual activity, persisting to adolescence controls the malevolence and, eventually, makes the child fully human (Dupuis 2007). In the Bolivian Andes, a precise and elaborate swaddling procedure guards the infant against susto, an illness that results in the separation of body and soul (de Suremain 2007). A caretaking style that emphasises keeping the infant in a coma-like state-always quiet and sheltered - is also often justified on the basis of insuring that the spirit doesn't flee (Reichel-Dolmatoff 1976: 277; Howrigan 1988: 41; Broch 1990: 31). Of course, this policy (along with using swaddling and cradle-boards) also reduces the amount of attention that the mother must devote to the infant.

“A [Mandok] newborn's inner self (апипи) was not yet firmly anchored inside its body... and for this reason both new parents observed many food and behavioral taboos after the birth... New fathers were prohibited from going fishing in channels and in deep water, nor could they hull out canoes, carve, or chop down trees...If the child cried inexplicably, the Mandok believed that one of the parents had violated a taboo that caused its anunu to leave. A ritual specialist was then called in to 'call the baby back'...As the child grew, the Mandok believed that the anunu gradually moved from 'the surface of the skin' to the inside of he body, a common belief in other areas of Melanesia as well (Pomponio 1992: 77).”

"A new-born [Punan Bah] child is considered little more than a mere body of blood, bones and flesh. Only gradually as the soul...takes up residence in the child, does it become human...The souls of children...can easily be scared away, and children must be handled with the greatest care at least till they are about four years old when they become more secure [for example, they are] never punished physically so as not to scare off their souls (Nicolaisen 1988: 198-9)."

"General or prolonged fussiness, a refusal to eat or outright sickness - all these may be diagnosed as symptomatic of the spirit's withdrawal from the body. To secure its permanent integration with the body, the [Qiqiktamiut] family and others make every effort to encourage it to remain [including] the maintenance of a congenial atmosphere... and the creation of important ritual ties to members of the community outside the natal household (Guemple 1979: 41-2)."

In the earlier discussion of the ecology of child health and survival, I noted that illness and death were likely. Hence, even if correct preventative practices are followed, parents must confront the reality of sick children. In the next section, I show how folk medical theory and practice is also informed by "Two Worlds" thinking.

\section{IIlness and Cure}

A great deal of the ethnographic literature in infancy records strategies for diagnosing illness or discomfort and corresponding remedies. You will note that an underlying theory in these prescriptions is that the child's well-being is compromised when it appears excited or agitated. Caretakers seek to remove the source of agitation-which may 
be spirit forces - and return the child to a "healthy," quiescent state. If these remedies fail, the cause is sought in malevolent or supernatural forces, not the mother or the family.

“[In rural Iran] Djenn are said to be after the mother's liver (jigar). They are also jealous of the baby, especially during the first ten, or better, forty, days; they might steal the baby or exchange it for their own, sickly one. A baby indicates that it might be a changeling by fussiness, weakness, or lack of growth (Friedl 1997: 69)."

"If an infant gets sick frequently, parents might give the child a new name- that of a blacksmith, for instance, or others who Tibetans consider to be of low birth — as a way of tricking malevolent forces into leaving the child alone... This act not only grounds the infant in this world, but also ties the child to his home and lineage (Craig 2009: 155)."

"During its first...months the babe is considered highly vulnerable to danger from local spirits. Infant mortality among rural Javanese is in fact high. ...slametan for the child follow at regular intervals during childhood, each accompanying a ritual event that introduces the child to a new, more secure stage in life (Jay 1969: 99)."

[In rural Japan] the Ubugoya was a place where the mother and the baby could hide themselves from ghosts and evil spirits...A baby was considered to be transferred into the human world by a god. A midwife...played a religious role in guiding the baby from the gods' world to the human world and giving social recognition to the baby as a member of the community (Yanagisawa 2009: 88)."

"[Aborigine] babies...were vulnerable to attacks by maтu....evil spirits that live in the bush. When an infant was bitten, his soul would fall ill and the baby got unwell (Tjitayi and Lewis 2011: 58-9)."

The "Two World" model underscores the child's vulnerability; its slender hold on life. But this impermanence may be construed in a more positive light. Quite a few societies, especially in ancient times, saw opportunity in the child's indeterminate - part spirit, part human — state. Because the child was not considered fully human, it was assumed to have extra-human capacities.

\section{Little Angels}

These innocent and pure spirits could be utilized to appease or otherwise communicate with the other world of ancestors and gods (Hearn 2007; Klaus, et al 2010). Child sacrifice is not uncommon. Infant and child remains are often recovered from "foundation deposits" at the base of important buildings (Sachs and Vu 2005; Scott 1999: 86; Colón with Colón 2001: 64; Moses 2008: 49). In an example from the ethnographic record, the Bolobo believe that exchanging his/her soul with the uncontaminated soul of an infant can save a bewitched adult. As the adult gradually recovers health, the infant sickens and dies (Viccars 1949: 223). Other examples from antiquity:

"Children were seen to possess this particular gift and were considered to have a position intermediate between the human world and that of the gods...Children were considered suitable for the task of prophesy, functioning as intermediaries between the divine and human worlds in Greco-Roman society (Horn and Martens 2009: 179)."

"[Japanese] saying "one of the gods until the age of seven'... Before seven, children were weak, and could die easily from sickness....they could instantly return to the world of the gods and Buddhas at any time...possess the power to transmit the will of the [deities] and often played the role of medium between gods and people (Kuroda 1998: 10)."

"[Aymara] children who die before being named and gaining godparents are buried in a place far from the household and the community cemetery where they are 'eaten' by the mountain spirits...because these unnamed and un-baptized children still belong to the world of the mountain deities and have not yet been socialized into the human world. Children only become truly human when they begin to walk and talk (Sillar 1994: 51)."

"The classical and biblical texts, as well as the archaeology, all indicate that healthy living children were sacrificed to the gods in the Tophet... The burned bones found inside jars from the Carthage Tophet provide conclusive evidence for Phoenician child sacrifice (Stager and Greene 2000: 31).”

"[Roman] children had long been used in religious and propitiatory ceremonies, because of the quality of purity often associated with children (Rawson 2003: 315).” 
"The greatest number of...sacrificial offerings [in Mayan cenotes to the water god Chac] were between four and ten years of age - precisely the period of greatest potential and liminality, given current understandings of ancient Mesoamerican conceptualizations of childhood. These children...still embodied the purity and connection to the spirit world that would erode gradually until they were approximately ten (Arden 2011: 142)."

These examples underscore that the child is in a liminal state - not yet fully human and not yet completely attached to the mother. These incomplete emotional bonds may enable the child's family to more easily relinquish the child to serve ritual ends.

\section{Little Devils}

Alternatively the infant may be viewed as threatening either in its own right or as a vessel or avatar for ghosts and evil spirits (Nath 1960: 187). In practical terms, this view may lead to caretaking behaviors that are similar to those deployed when children are seen as transient spirits with special powers. Whether children were seen as pure and innocent or as threatening, the effect on childcare practices might be the same.

"Protestant and Catholic dogma influenced the inclusion of infants within cemeteries. Newborns were considered to be corrupted by the original sin of their conception, and unbaptized or stillborn infants were not permitted burial in consecrated ground (Lewis 2007: 33)."

"[Certain] births coincide with the intensely active and aggressive phase of the yearly yin/yang cycle, thereby imbuing the nature of such neonates with these dangerous traits...Han histories suggests that parents who believed these predictions typically abandoned or killed ill-omened children rather than attempting to "transform" them" (Kinney 1995: 24)."

"They did not consider infanticide itself an immoral act. The basic reason for this was that newborns are categorized as inhuman. Consistent with the perception that birth processes are repulsive and dangerous, Korowai say that a newborn is "demonic" (laleo) rather than "human" (yanop). People explain this categorization by noting that a newborn's skin is uncannily pale, that newborns are torpid, and that their bodies are generally freakish (Stasch 2009: 151)."

"When a [Pamiri] child is born and fidgets and cries [a lot] and he has a black circle around his mouth and eyes, it means that he may have jinn [genie or spirit]. To solve the problem, one has to open the child's mouth and look at the roof of his mouth. If you observe black veins, you need to make a hole in the veins with a needle and mop up the blood with a swab. The child gets better and does not cry again (Keshavjee 2006: 75)."

"The belief that infants were felt to be on the verge of turning into totally evil beings is one of the reasons why they were tied up, or swaddled, so long and so tightly (Haffter 1986: 11)."

Because the very young are seen as a potential conduit allowing the transmission of dangerous forces into the family or community, steps have to be taken to guard against this possibility. These steps include practices like baptism, swaddling, avoiding eye contact with the infant, or bloodletting. However, one of the greatest threats posed by the spirit child is to thwart a mother's ardent desire for offspring. To counter this threat, truly drastic measures are required.

\section{Tricksters}

Across Nigeria, the cultural model of infancy includes the notion that the spirit intends to trick its parents by continually being reborn but then returning to its true abode. The remedies for breaking this endless cycle of rebirth are severe.

"If [Ijaw] parents have experienced several infant deaths, one after another, they usually suspect that the same child is coming to them each time (Leis 1982: 156-7)."

"Abiku children are "born to die"; after living with their parents for only a little while, they leave to rejoin the spirit companions who have always been tempting them to return. Sometimes, [the Yoruba] believe, the same $a b i k u$ child will come back time and again to torment the parents with its temporary presence, only to die in due course...This belief in abiku children may be operating as a necessary and ingenious explanation for the high 
rate of infant deaths, providing a satisfactory framework within which such distressing episodes may be accepted (Maclean 1994: 161)."

"[The deceased child of an Ibo mother who's lost several in succession] is deemed unlucky, and cannot live in this world. The faster it is blotted out of existence the better.... Dismembering the body before it is burned is also very common. The ashes are usually scattered to the four winds...Hanging the body from a tree and letting it rot...is another common disposal method for the child. (Basden 1966: 282)."

Another version of the infant as trickster is found among the Toradja of Sulawesi.

"[Such] children were...put away in a hole that was made in a large, living tree... The body was placed...on end, with the head downward... after which the hole was nailed shut with a small board. This was done so that the child's tanoana would not return to earth and call the tanoana of other children, so that the latter would also be stillborn or die soon after birth (Adriani and Kruijt 1950: 708-9)."

Our data is not limited to the accounts of ethnographers or historians. Archaeological excavations and analyses of post-mortem treatment of the young offer very strong support for the claim that personhood is delayed.

\section{Post-Mortem Treatment and Delayed Personhood}

Several lines of evidence drawn from the way in which infants and children are treated in death strongly reinforce the delayed personhood argument (Senior 1994) and, in turn, signal the need to resist attachment. First of all, burial rites and mourning may be minimal or actively discouraged in the case of a child younger than five (Fricke 1994: 133; Ndege 2007: 103) or, even as late as ten (Rawson 2003: 104). The variability is consistent with the variability in marking the age at which the child is considered a person. The attention of the family and community should be on the next child, not on the one that's died. For example, "the average duration of a birth interval is substantially shorter following an infant death than when an infant survives (Kramer and Greaves 2007: 720)."

"It is not unusual for the [Ayoreo] newborn to remain unnamed for several weeks or months, particularly if the infant is sickly. The reason given is that should the child die, the loss will not be so deeply felt (Bugos and McCarthy 1984: 508)."

"[Bagesu] children often died at birth or in infancy, and the bodies were thrown out into the bush (Roscoe 1924: 25)."

"[When a Chippewa infant died] weeping was frowned upon for the fear that the sorrow would be passed on to the next child (Hilger 1951: 79)."

"When a [Tonga] child died before it was named, there was no mourning for no shades were involved...the old women will tell the mother to hush her wailing, saying this is only a ghost (cello) (Reynolds 1991: 97)."

When we turn to the archaeological record, excavators find that, save for a few societies such as ancient Egypt (Meskell 1994), and during the city-state period in Athens (Houby-Nielsen 2000), infants and children were buried apart from older children and adults (King 2006: 185).

"Children's remains located outside the confines of communal burial grounds are a common finding throughout the world, and during all time periods (Lewis 2007: 31).”

"In Xaltocan...burials of infants and young children less than four years of age were recovered...under room floors and...also incorporated into house walls (De Lucia 2010: 612-3).”

"[Mapuche] infants are not buried in the cemetery, but are buried in the old family plot or somewhere near the house, it is believed that it would be harder for the child to be turned into a demon if it is closer to the house (Faron 1964: 91)."

"In Early Mycenaean Greece, infants of less than one year of age were differentiated by their total exclusion from organized extramural cemetery areas and by the absence of complete vases in their graves. ... Children of between 1-2 and 5-6 years of age were still only included in formal extramural cemeteries in exceptional cases (Lebegyiv 2009: 27)." 
"An analysis of Etruscan child burials in Tarquinia enables one to conclude that the absence of children below the age of five and a half years from the principal cemeteries was suggestive of a major shift at that age (Becker 2007: 292).”

A review of post-mortem practices, including any funerary and internment rites, complements the ethnographic record. The data underscore the child's liminality and lack of integration into the social world of the community. At death, it is mourned privately or not at all and it is interred discretely, without ceremony.

\section{Discussion}

My purpose here has not been to argue for the abandonment of attachment theory. It is hard to argue against the need for some degree of attachment. For example, "without attachment...infants would not survive. They...would lack the basic propensity ... to maintain proximity with the resources they depend upon (Rochat 2009: 156)." Rather the goal has been to use the archives of anthropology and history to interrogate or critique many of the corollary claims made by Bowlby and his successors. For example, Bowlby argued that it was "essential for mental health that the infant and young child should experience a warm, intimate and continuous relationship with his mother...in which both find satisfaction and enjoyment (Bowlby 1953: 11)." These arguments - particularly regarding the nature and effect of "maternal deprivation"- have not gone unchallenged by child development scholars (Clarke and Clarke 2000; Tizard and Tizard 1974) and cultural anthropologists (LeVine 2004). Nevertheless, many of Bowlby's more extreme arguments are sustained and expanded upon in the writing of his successors (Karen 1998; Newton and Schore 2008) who espouse "attachment parenting." The advocates operate from an assumption of universality - that the dictates of attachment parenting should be immune from significant cross-cultural variation.

In the survey reported here, the intent has been to go beyond merely identifying societies that don't seem congenial to attachment theory (e.g. Erchak 1992; Paradise 1996). With an extremely large and diverse database of cases, I have been able to find common patterns within the cross-cultural variability and construct both general and more specific models of infancy. These models can be used as lenses to examine claims made regarding the essential components of psychologically healthy infancy. "Attachment Theory" and its descendants have created a narrative of infants "at risk" of emotional maladjustment. In this survey of sources from cultural anthropology, history and archaeology this perceived risk is absent. It is to be presumed that infants' emotional needs are met simultaneous with their need for sustenance and nothing further need be done. The survey also reveals that an alternate narrative identifies attachment rather than attachment failure as the risk. A strong, emotional bond is seen as impeding a process whereby infants get pragmatically sorted into categories of wanted vs. unwanted, timely vs. untimely, legitimate versus illegitimate, strong fighters vs. sickly ghosts, innocent versus demonized and, either voluntarily or involuntarily extinguished. The risk of inopportune attachment is met by an overarching cultural model that denies the newborn personhood - often until it is several months if not years old. Personhood is delayed until the child's spirit and body become firmly united and the individual "ripens" into an independent and unique being capable of social interaction.

A very thorough survey has failed to provide much evidence for maternal concern for the infant's emotional security nor evidence of such concern in the cultural models of the infancy and early childhood period - just the contrary. We might then ask what are the cultural and historical forces shaping attachment theory or attachment parenting in the modern era? With the decline in infant mortality and beliefs re changelings and other malevolent incarnations of the infant, we should expect that restraints on attachment will be relaxed. Improved access to resources has reduced the need for infanticide and child labour. Various forces have combined, leading to lower birth rates. Contemporary parents now see their (fewer) offspring not as investments for the future but as providing emotional rewards in the present. Where much of the world can be considered a "gerontocracy" with ancestors and elders on top and children at the bottom, the society that has embraced attachment parenting is clearly a "neontocracy" with children at the apex of the value scale (Lancy 2008: 25-6). Caring for infants has become a pleasure rather than a burden. Adults' dignity is not impaired when they play with their children. Frequent gestures and words of affection exchanged between parents and children have become the norm. However, while genuine threats to the child's safety, health and nutrition have declined dramatically in the last century, parental anxiety, seemingly, has not. The list of fearssometimes quite irrational — such as fear of the child's abduction (Tulloch 2004), has grown quite long. These include concern for the child's happiness, which historians trace to the early twentieth-century Stearns (2010: 172); exaggerated and misguided concern for the child's self-esteem (Baumeister et al 2005) and; quite recently, the curtailment of children's free play as exposing the child to unacceptable risks (Lancy and Grove 2011b) to name just a few. I would suggest that the fear that a normal child growing up in an average middle class home is at risk for reactive attachment disorder (RAS) flows from the same thinking. Collectively, these concerns have the effect of 
constantly raising the bar for what is considered adequate parenting. Push back from women and policy makers has led to the launching (in the US) of the "Mommy Wars." On one side are those who argue that raising a healthy and successful child requires the full-time attention of the mother while, on the other, are those who feel that children require less care which can be delivered by a range of caretakers (Steiner 2007).

There may be little doubt that evolution would have favored the formation of bonds of attachment between a child and his/her caretaker(s). However, it is not at all clear that these bonds can only form if the caretaker is in constant attendance and quickly meets the infant's every need for sustenance, comfort, attention, affection and, entertainment. Hence, much of attachment theory in both original and attachment parenting versions reflects not universal, species-wide adaptations but, rather, adaptations to a very recent and culture-specific model of infancy. And, unlike the widely accepted "delayed personhood," view, in this contemporary model, personhood now begins with conception, if not before.

Appendix 1: Geographic Distribution of Sample

Europe (Mesolithic-Georgiadis 2011) (Alexandre-Bidon and Lett 1999) (Etruscans-Becker 2007) (SicilianChapman 1971) $\left(17^{\text {th }}-19^{\text {th }}\right.$ century Europe-Cunningham 1995) (Venice-Ferraro 2008) (Houby-Nielsen 2000) (Greece-Kleijueqgt 2009) (Morel 2007) (Mycenaean Greece-Lebegyiv 2009) (Early Modern-Lewis 2007) (Medieval England-Orme 2003) (Rome-Rawson 2003) (Middle Ages-Hanawalt 2003) (Vlach-Campbell 1964) (Iron AgeWoolf 1997) (Rome-Wileman 2005) (Neolithic-Scott 1999) (Neolithic-Le Mort 2008) (Early Bronze Age-Rega 1997) (Rome-Wiedemann 1989) (Medieval-Goodich 1989) (Early Modern-Gillis 2003) (Middle Ages-Haffter 1986) (Roma-Fonseca 1995) (Hungary-Bereczkei 2001) (18 ${ }^{\text {th }}$ c. Russia-Dunn 1974) (Contemporary Germany-LeVine and Norman 2001)

North Africa (Ancient Carthage, Rome-Lee 1994) (Ancient Egypt-Meskell 1994) (Ancient Carthage-Stager and Greene 2000) (Kerkenneh-Platt 1988)

Eastern Africa (Northern Somalia-Cerulli 1959) (Southern Somalia-Helander 1988) (Anyi-Pourchez 2007) (NuerScheer and Groce 1988) (Gusii-LeVine 2004) (Lugbara-Middleton 1965) (Datoga-Sellen 1998) (Gogo-Mabilia 2000) (Masaai-De Vries 1987)

Central Africa (Nzebi-Dupuis 2007) (Azande-Evans-Pritchard 1932) (Songye-Devleiger 1995) (Bagesu-Roscoe 1924) (Bobangi-Viccars 1949) (Macha Galla-Batels 1969) (Azande-Baxter 1953) (Bofi-Fouts 2005)

West Africa (Manjak-Teixeira 2007), (Gouro-Haxaire 2007) (Soninké-Razy 2007) (Ibo-Basden 1966) (FulaniCastle 1994) (Akan-Rattray 1927) (Nankani-Denham, et al 2010) (Kpelle-Erchak 1976) (Hausa-Faulkingham1970) (Anyi-Duchesne 2007) (Ibo-Henderson 1972) (Nso-Keller 2007) (Mossi-Bonnet 2007) (Dogon-Scheer and Groce 1988) (Ijaw-Leis 1982) (Mossi-Mangin 1921) (Bariba-Sargent 1988) (Papel-Einarsdottir 2004) (Sisala-Grindal 1972) (Mende-Fermé 2001) (Beng-Gottlieb 2000) (Mandinka-Whittemore 1989) (Songhay-Stoller 1989) (DogonDettwyler 1994) (Dogon-Strassmann 1997) (Yoruba-Maclean 1994) (Talensi-Fortes 1970) (Kpelle-Erchak 1992) (Fulani-Johnson 2000) (Fulani-Riesman 1992) (Hausa- Tomlinson, et al 2010) (Yoruba-Zeitlin 1996) (FulaniHampshire 2001)

Southern Africa (Madagascar-Blanchy 2007) (Umbundu-Childs 1949) (Tsonga-Green et al 1994) (MozambiqueNdege 2007) (Ngoni-Read 1960) (!Kung-Shostak 1981) (!Kung-Howell 1979) (Tonga-Reynolds 1991)

North America (Netsilik Eskimo-Balikci 1970) (Qiqiktamiut Inuit-Guemple 1979) (Inupiaq-Sprott 2002)(Chippewa-Hilger 1951) (Puritans-Mintz 2004) (Victorian era-Calvert 2003) (Tlingit-De Laguna 1965) (InuitWileman 2005) (Klamath-Pearsall 1950) (Navajo-Leighton and Kluckhohn 1948) (Tlingit-Colón with Colón 2001) (Netsilik-Riches 1974) (contemporary bourgeois-Baumrind 1971)

Highland South America (Bolivian Andes-de Suremain 2007) (Aymara-Buechler and Buechler 1971) (MapucheFaron 1964) (Muchik-Roach 2010) (Aymara-Arnold 2006) (Inka-Shein 1992) (Inka-Sillar 1994) (Quechua-Sillar 1994) (Inka-Besom 2009) (Barrio-Morgan 1998) (Quechua-Tronick,et al 1994)

Lowland South America (Mbya-Remorini 2011) (Ayoreo-Bugos and McCarthy 1984) (Yanomamo-Chagnon 1968) (Wari-Conklin and Morgan 1996) (Cubeo-Goldman 1963) (Mehinacu-Gregor 1970) (Mundurucu-Murphy and Murphy 1985) (Bakairí-Picchi 2000) (Huaorani-Rival 1998) (Ayoreo-Bugos and McCarthy 1984) (Yukui- 
Stearman 1989) (Tapirapé-Wagley 1977) (Bororo-Fabian 1990) (Barrio-Scheper-Hughes 1987) (Ache-Hill and Hurtado 1996) (Airo-Pai-Belaunde 2001)

Mesoamerica (Mixtec-Katz 2007) (Pre-Hispanic Maya-Tiesler 2011) (Pre-Hispanic Maya-Arden 2011) (Tlatelolco and Tenochtitlan-Berrelleza and Balderas 2006) (Toltec-Hearn 2007) (Aztec-Heilbrunn ND) (Coastal Oaxaca-King 2006) (Early colonial Chile and Peru-Allison 1984) (Zincantec Maya-de León in press) (Tarahumara-Mull and Mull 1987) (Pre-colonial Maya-Sharer 1994) (Yucatec Maya-Howrigan 1988) (Kogi-Reichel-Dolmatoff 1976)

Melanesia (Anangu-Eickelkamp 2011) (Warungka-Musharbash 2011) (Aboriginal central Australia-Tjitayi and Lewis 2011) (Bumbita Arapesh-Leavitt 1989) (Baining-Fajans 1997) (Drysdale River Tribes, North-West AustraliaHernandez 1941) (Sepik Region, Papua New Guinean-Kulick and Stroud 1993) (Ambonwari-Telban 1997) (Mandok-Pomponio 1992) (Vanatinai-Lepowsky 1987) (Korowai-Stasch 2009) (Kaliai-Counts 1985) (GapunKulick 1992) (Amele-Jenkins, et al 1985) (Trobriands-Montague 1985) (Bena-Bena-Langness 1981) (EipoSchiefenhovel 1989) (Asabano-Little 2008)

Polynesia/Micronesia (Maori-Best 1924) (Truk-Fisher 1963) (Hawaiian-American-Howard 1973) (PrehistoricKinaston, et al. 2009) (Ulithi, Micronesian Lessa 1966) (Tonga-Morton 1996)

East Asia (Edo period Japan-Kuroda 1998) (Ainu-Batchelor 1927) (Ch'ing Dynasty China-Furth 1987) (MiaoGraham 1937) (Yami-Arnaud 2007) (Hong Kong-Martin 2001) (Contemp. Japan-Lebra 1994) (Korean-Kim and Choi 1994) (Japan-Yanagisawa 2009) (China-Harvey and Buckley 2009) (Historic China- Kinney1995) (JapanKojima 2003) (Hokkien-Wolf 1972)

West Asia (Neo-Babylonian and Neo-Assyrian-MacGinnis 2011) $\left(4^{\text {th }}\right.$ century C.E. Constantinople-Alberici and Harlow 2007) (Neolithic-Wileman 2005) (Pottery Neolithic-Scott 1999) (Neolithic-Moses 2008) (Bedouin-Karplus and Karplus 1989) (Byzantium-Smith and Kahila 1992) (Turkey-Kagitcibasi and Ataca 2005)

Central Asia (Tamang-Fricke 1994) (Lepchas-Gorer 1938) (Pamiri-Keshavjee 2006) (Tibet-Craig 2009) (NurzayCasimir, 2010) (Tibet-Maiden and Farwell 1997) (Ladakh-Wiley 2004) (Tamang-Fricke 1994) (Bakkarwal-Rao 1998) (Yomut-Irons 2000) (Punjab-Miller 1987)

SE Asia (Nayaka-Bird-David 2005) (Bonerate-Broch 1990) (Javanese-Geertz 1961) (Nso-Keller 2007) (India-Kopp, et al 1977) (Mentawai Islands-Loeb 1962) (Bali-Covarrubias 1937) (Southern India-Nichter and Nichter 1987) (Hmong-Liamputtong 2009) (Javanese-Jay 1969) (Bils-Nath 1960) (Barrio-Jocano 1969) (Dongria-Hardenberg 2006) (Punan Bah-Nicolaisen 1988) (Tamil-McGilvray 1994) (Bengali-Bhattacharyya 1981) (Bajau-Nimmo 1970) (Semai-Dentan 1978) $\left(11^{\text {th }}\right.$ century Hanoi-Sachs and Vu 2005) (Chewong-Howell 1988)

\section{References}

Adriani, Nicolaus and Kruijt, Albertus C. 1950. The Bare'e-Speaking Toradja of Central Celebes. Amsterdam, The Netherlands: Noord-Hollandsche Uitgevers Maatschapp ij.

Ainsworth, Mary D. 1967. Infancy in Uganda: Infant Care and the Growth of Love. Baltimore, MD: Johns Hopkins Press.

Ainsworth, Mary D. S., Blehar, Mary C., Waters, Everett, and Wall, Sally 1978. Patterns of Attachment: A Psychological Study of the Strange Situation. Hillsdale, NJ: Erlbaum.

Alber, Erdmute 2004. "The real parents are the foster parents": Social parenthood among the Baatombu in Northern Benin. In Fiona Bowie (Ed.), Cross Cultural App roaches to Adoption. pp . 33-47. London, UK: Routledge.

Alberici, Lisa A. and Harlow, Mary 2007. Age and innocence: Female transitions to adulthood in late antiquity. In Cohen, Ada and Rutter, Jeremy B. (Eds.), Constructions of Childhood in Ancient Greece and Italy. (Pp. 193-203). Princeton, NJ: The American School of Classical Study at Athens.

Alexandre-Bidon, Daniéle and Lett, Didier 1999. Children in the Middle Ages: Fifth-Fifteen Centuries. Notre Dame, IN: The University of Notre Dame Press. 
Allison, Marvin J. 1984. Paleopathology in Peruvian and Chilean populations. Mark N. Cohen and George J. Armelagos (Eds.). In Paleopathology at the Origins of Agriculture, (Pp. 531-558). Orlando, FL: Academic Press.

Arden, Traci 2011. Empowered children in classic Maya sacrificial rites. Childhood in the Past 4: 133-45.

Arnaud, Veronique 2007. "La soullure des exocets s'envole à jamais!" Rite prophylactiques relatifs aus enfants Yami. (Botel Tobago, Taïwan). In Bonnet, Doris and Pourchez, Laurence (Eds) Du Soin au Rite dans L'infance. (Pp. 183-209) Paris: IRD.

Arnold, Denise Y. 2006. The Metamorphosis of Heads: Textual Struggles, Education, and Land in the Andes. Pittsburgh, PA: University of Pittsburgh Press.

Badinter, Elizabeth 2012. The Conflict: How Modern Motherhood Undermines the Status of Women. New York: Metropolitan Books.

Balikci, Asen 1970. The Netsilik Eskimo. Garden City, NY: The Natural History Press.

Basden, George T. 1966. Niger Ibos: A Description of the Primitive Life, Customs and Animistic Beliefs, etc., of the Ibo People of Nigeria. London: Frank Cass.

Batchelor, John 1927. Ainu Life and Lore: Echoes of a Departing Race. Tokyo: Kyobunkwan.

Batels, Lambert 1969. Birth customs and birth songs of the Macha Galla. Ethnology, 8: 406-422.

Baumeister, Roy F., Campbell, Jennifer D., Krueger, Joachim I., Vohs, Kathleen D. 2005. Exploding the self-esteem myth. Scientific American Mind, 16(4): 50-7.

Baumrind, Diana 1971. Current patterns of parental authority. Developmental Psychology Monographs 4 (No. 1, Part 2): 1-103.

Baxter, Paul T.W. 1953. The Azande, and Related Peoples of the Anglo-Egyptian Sudan and Belgian Congo London: International African Institute.

Becker, Marshall J. 2007. Childhood among the Etruscans; Mortuary programs at Tarquinia as indicators of the transition to adult status. In Ada Cohen and Jeremy B. Rutter (Eds.), Constructions of Childhood in Ancient Greece and Italy. (Hesperia Supplement 410). pp. 281-92. Athens: American School of Classical Studies at Athens.

Belaunde, Luisa E. 2001. Menstruation, birth observances and the couple's love amongst the Airo-Pai of Amazonian Peru. In Soraya Tremayne (Ed.). Managing Reproductive Life: Cross-Cultural Themes in Sexuality and Fertility. (Pp. 127-139). Oxford: Berghahn Books.

Bereczkei, Tomas 2001. Maternal trade-off in treating high-risk children. Evolution and Human Behavior, 22: 197212.

Berrelleza, Juan Alberto Roman and Balderas, Ximena Chavez 2006. The role of children in the ritual practices of the Great Temple of Tenochtitlan and the Great Temple of Tlatelolco. In Traci Adren and Scott R. Hutson (Eds.). The Social Experience of Childhood in Ancient Mesoamerica, (Pp. 233-248). Boulder, CO: University of Colorado Press.

Best, Elsdon 1924. The Maori. (Vol 2) Wellington, N.Z.: H.H. Tombs.

Besom, Thomas 2009. Of Summits and Sacrifice: An Ethnohistoric Study of Inka Religious Practices. Austin, TX: University of Texas Press.

Bhattacharyya, Deborah P. 1981. Bengali Conceptions of Mental Illness. Unpublished Ph.D. dissertation, Indiana University, Bloomington, Indiana.

Blanchy, Sophie 2007. Le tambavy des bébés à Madagascar: du soin au ritual d' ancestralité. In Doris Bonnet and Laurence Pourchez (Eds.), Du Soin au Rite dans L'infance. pp . 146-66. Paris: IRD. 
Bonnet, Doris 2007. La toilette des nourissons au Burkina Faso: Une manipulation gestuelle et sociale du corps de l'enfant (Bathing Mossi babies: A social and cultural practice). In Doris Bonnet and Laurence Pourchez (Eds), Du Soin au Rite dans L'infance. pp . 113-28. Paris: IRD.

Boserup, Ester 1970. Women's Role in Economic Development. London: Allen and Unwin.

Bowlby, John 1953. Child Care and the Growth of Love. Hammondsworth: UK Penguin Books, Ltd.

Bird-David, Nurit 2005. Studying children in "Hunter-Gatherer" societies: Reflections from a Nayaka perspective. In Barry S. Hewlett and Michael E. Lamb (Eds.), Hunter Gatherer Childhoods: Evolutionary, Developmental, and Cultural Perspectives. pp. 92-101. New Brunswick, NJ: AldineTransaction.

Broch, Harald B. 1990. Growing up Agreeably: Bonerate Childhood Observed. Honolulu, HI: University of Hawaii Press.

Buechler, Hans C. and Buechler, Judith-Maria 1971. The Bolivian Aymara. New York: Holt, Rinehart and Winston.

Bugos, Peter E, Jr. and McCarthy, Lorraine M. 1984. Ayoreo infanticide: A case study. In Glen Hausfater and Sarah B. Hrdy (Eds.), Infanticide: Comparative and Evolutionary Perspectives. pp. 503-20. New York, NY: Aldine.

Calvert, Karen 2003. Patterns of childrearing in America. In Willem Koops, and Michael Zucherman (Eds.) Beyond the Century of the Child: Cultural history and Developmental Psychology. (Pp. 62-81). Philadelphia: University of Pennsylvania Press.

Campbell, John K. 1964. Honour, Family, and Patronage: A Study of Institutions and Moral Values in a Greek Mountain Community. Oxford: Clarendon Press.

Castle, Sarah E. 1994. The (re)negotiation of illness diagnoses and responsibility for child death in rural Mali. Medical Anthropology Quarterly 8(3): 314-35.

Casimir, Michael J. 2010. Growing Up in a Pastoral Society: Socialization Among Pashtu Nomads. Kölner Ethnologische Beiträge. Köln: Druck and Bindung.

Cerulli, Enrico 1959. The Consuetudinary Law of Northern Somalia. Vol. II. Rome, Italy: A Cura dell'Amministrazione Fiduciaria Italiana della Somalia.

Chagnon, Napoleon A. 1968. Yanomamo: The Fierce People. New York: Holt, Reinhart and Winston

Chapman, Charoltte G. 1971. Milocca: A Sicilian Village. Cambridge, MA: Schenkman.

Childs, Gladwyn M. 1949. Umbundu Kinship and Character: Being a Description of Social Structure and Individual Development of the Ovimbundu of Angola. London: Published for the International African Institute by the Oxford University Press.

Clarke, Ann M. and Clarke, Alan D.B. 2000 Early Experience and the Life Path. London: Jessica Kingsley Pub.

Colón, Angel R. with Colón, Patricia A. 2001. A History of Children: A Socio-Cultural Survey Across Millennia. Westport, CT: Greenwood Press.

Conklin, Beth A. and Morgan, Lynn M. 1996. Babies, bodies, and the production of personhood in North America and a Native Amazonian society. Ethos 24: 657-694.

Counts, Dorothy A. 1985. Infant Care and Feeding in Kaliai, West New Britain, Papua

New Guinea. In Marshall, Leslie B. (Ed.) Infant Care and Feeding in the South Pacific. (Pp.155-169), New York: Gordon and Beach Science.

Covarrubias, Miguel 1937. Island of Bali. New York: Alfred E, Knopf. 
Craig, Sienna R. 2009. Pregnancy and childbirth in Tibet: Knowledge, perspective, and practices. In Helaine Selin and Pamela K. Stone (Eds.). Childhood across Cultures: Ideas and Practices of Pregnancy, Childbirth and the Postpartum. pp. 145-60. Amherst, MA: Springer.

Cunningham, Hugh 1995. Children and Childhood in Western Society since 1500. New York: Longman.

Daly, Martin and Wilson, Margo. 1984. A sociobiological analysis of human infanticide. In Glenn Hausfater and Sarah Blaffer Hrdy (Eds.), Infanticide: Comparative and Evolutionary Perspectives. pp. 487-502. New York: Aldine.

D'Andrade, Roy and Strauss, Claudia 1992. Human Motives and Cultural Models. Cambridge: Cambridge University Press.

de Laguna, Frederica 1965. Childhood among the Yakutat Tlingit. In Melford E. Spiro (Ed.), Context and Meaning in Cultural Anthropology. (Pp. 3-23). New York: Free Press.

de León, Lourdes in press. 'The $j$ 'Ik'al is coming!' Triadic directives and emotion in the socialization of Zinacantec Mayan children. In Alain Breton and Phillipe Nodédéo (Eds) Maya Daily Lives: Proceedings of the $13^{\text {th }}$ European Maya Conference. Markt Schwaben, Germany: Anton Saurwein.

de Lucia, Kristin 2010. A child's house: Social memory, identity, and the construction of childhood in early Postclassic Mexican households. American Anthropologist 112(4): 607-24.

Denham, Aaron R., Adongo, Philip B., Freydberg, Nicole, Hodgson, Abraham 2010. Chasing spirits: Clarifying the spirit child phenomenon and infanticide in Northern Ghana. Social Science \& Medicine 71: 608-615.

Dentan, Robert K. 1978. Notes on childhood in a nonviolent context: The Semai case. In Ashley Montague (Ed.), Learning Non-Aggression: The Experience of Non-Literate Societies. pp . 94-143. Oxford: Oxford University Press.

Dettwyler, Katherine A. 1994. Dancing skeletons: Life and death in West Africa. Waveland: Prospect Heights, Ill.

de Suremain, Charles-Édouard 2007. Au fil de la faja. Enrouler et dérouler la vie en Bolivie. In Doris Bonnet and Laurence Pourchez (Eds.), Du Soin au Rite dans L'infance. pp. 85-102. Paris: IRD.

Devereux, George 1955. A Story of Abortion in Primitive Societies. New York: Julian Press.

Devleiger, Patrick 1995. Why disabled? The cultural understanding of physical disability in an African Society. In Benedicte Ingstad and Susan Reynolds Whyte (Eds.), Disability and Culture. pp . 94-133. Berkeley, CA: University of California Press.

DeVries, Marten W., 1987. Alternatives to mother-infant attachment in the neonatal period. In Super, Charles (Ed.), The Role of Culture in Developmental Disorder. (Pp 109-130). New York: Academic Press Inc.

Dickeman, Mildred 1975. Demographic consequences of infanticide in man. Annual Review of Ecology and Systematics 6: 107-37.

Duchesne, Véronique 2007. Le ritual de possession: Un jeu d'enfants? Jeux enfantines et pratique religieuse. In Bonnet, Doris and Pourchez, Laurence (Eds) Du Soin au Rite dans L'infance. (Pp. 231-240) Paris: IRD.

Dunn, Patrick 1974. "That enemy is the baby": childhood in Imperial Russia. In Lloyd deMause (Ed.) The History of Childhood. (Pp. 383-405). New York: Harper \& Row.

Dupuis, Annie 2007. Rites requis par la naissance, la croissance et la mort des jumeaux. Leur aménagement dans le monde modern. Le cas de Nzebi du Gabon. In Bonnet, Doris and Pourchez, Laurence (Eds.), Du Soin au Rite dans L'infance. pp. 255-80. Paris: IRD.

Eickelkamp, Ute 2011. Sand storytelling: Its social meaning in Anangu children's lives. In Ute Eickelkamp (Ed.), Growing up in Central Australia: New Anthropological Studies of Aboriginal Childhood and Adolescence. Pp. 10330. Oxford: Berghahn Books. 
Einarsdottir, Jonina 2004. Tired of Weeping: Mother Love, Child Death, and Poverty in Guinea-Bissau. Madison, WI: The University of Wisconsin Press.

Erchak, Gerald M. (1976/77). Who is the $\underline{Z_{0}}$ ? A study of Kpelle identical twins. Liberian Studies Journal 7(1) 2325.

Erchak, Gerald M. 1992. The Anthropology of Self and Behavior. New Brunswick, NJ: Rutgers University Press.

Evans-Pritchard, Edward E. 1932. Heredity and gestation, as the Azande see them. Sociologus 8:400-414.

Fabian, Stephen M. 1992. Space-time of the Bororo of Brazil. Gainesville, FL: University Press of Florida.

Fajans, Jane 1997. They Make Themselves: Work and Play Among the Baining of Papua New Guinea. Chicago, IL: University of Chicago Press.

Faron, Louis C. 1964. Hawks of the Sun: Mapuche Morality and its Ritual Attributes. Pittsburgh, PA: University of Pittsburgh Press

Faulkingham, Ralph H. 1970. Bases of Legitimacy for Social Control in a Hausa Village. Unpublished Ph.D.

Dissertation, Lansing, MI: Michigan State University.

Fabian, Stephen M. 1990. Space-time of the Bororo of Brazil. Gainseville, FL: University Press of Florida.

Fermé, Mariane C. 2001. The Underneath of Things: Violence, History, and the Everyday in Sierra Leone. Berkeley, CA: University of California Press.

Ferraro, Joanne M. 2008. Nefarious Crimes, Contested Justice: Illicit Sex and Infanticide in the Republic of Venice, 1557-1789. Baltimore, MD: Johns Hopkins University Press.

Fisher, Ann 1963. Reproduction in Truk. Ethnology. 2: 526-540.

Flinn, Mark V., and England, Barry G. 2002. Childhood stress: Endocrine and immune responses to psychosocial events. In James M. Wilce (Ed.), Social and Cultural Lives of Immune Systems. Pp. 107-47. London: Routledge

Fonseca, Isabel 1995. Bury Me Standing: the Gypsies and Their Journey. New York: Vintage Books.

Fortes, Meyer 1970. Social and psychological aspects of education in Taleland. In John Middleton (Ed.), From Child to Adult: Studies in the Anthropology of Education. (Pp. 14-74). Garden City, NY: The Natural History Press.

Fouts, Hilary N. 2005. Families in Central Africa: A comparison of Bofi farmer and forager families. In Jaipaul L. Roopnarine (Ed.), Families in Global Perspective. pp. 347-63. Pearson.

Fricke, Tom 1994. Himalayan Households: Tamang Demography and Domestic Process. New York: Columbia University Press.

Friedl, Erika 1997. Children of Deh Koh: Young Life in an Iranian Village. Syracuse, NY: Syracuse University Press.

Furth, Charlotte 1987. Concepts of pregnancy, childbirth, and infancy in Ch'ing Dynasty China. Journal of Asian Studies. 46: 7-34.

Geertz, Hildred 1961. The Javanese Family: A Study of Kinship and Socialization. New York: Free Press.

Georgiadis, Mercourios. 2011. Child burials in Mesolithic and Neolithic Southern Greece: A synthesis. Childhood in the Past 4: 31-45. 
Gillis, John R. 2003. The birth of the virtual child: A Victorian progeny. In Willem Koops, and Michael Zucherman (Eds.) Beyond the Century of the Child: Cultural History and Developmental Psychology. (Pp.82-95), Philadelphia, Pa: University of Pennsylvania Press.

Goldman, Irving 1963. The Cubeo: Indians of the Northwest Amazon. Urbana, IL: University of Illinois Press.

Goodich, Michael E. 1989. From Birth to Old Age: The Human Life Cycle in Medieval Thought, 1250-1350. Lanham,MD: University Press of America.

Gorer, Geoffrey 1938. Himalayan Village: An Account of the Lepchas of Sikkim. London: Michael Joseph, Ltd.

Gottlieb, Alma 1995. Of cowries and crying: A Beng guide to managing colic. Anthropology and Humanism 20: 208.

Gottlieb, Alma 2000. Luring your child into this life: A Beng path for infant care. In Judy DeLoache and Alma Gottlieb (Eds.), A World of Babies: Imagined Childcare Guides for Seven Societies. pp. 55-90. Cambridge: Cambridge University Press.

Graham, David C. 1937. The Customs of the Ch'uan Miao. Shanghai: Thomas Chu and Sons.

Green, Edward C., Jurg, Annemarie and Djedje, Armando 1994. The snake in the stomach: Child diarrhea in Central Mozambique. Medical Anthropology Quarterly 8(1): 4-24

Gregor, Thomas 1970. Exposure and Seclusion: A study of institutionalized isolation among the Mehinacu Indians of Brazil. Ethnology 9(3): 234-250.

Grindal, Bruce T. 1972. Growing up in Two Worlds: Education and Transition Among the Sisala of Northern Ghana. New York: Holt, Rinehart, and Winston.

Guemple, D. Lee 1979. Inuit socialization: A study of children as social actors in an Eskimo community. In Karigoudar Ishwaran (Ed.), Childhood and Adolescence in Canada. pp. 39-71. Toronto, Canada: McGraw-Hill Ryerson.

Haffter, Carl 1986. The changeling: Hstory and psychodynamics of attitudes to handicapped children in European folklore. Journal of the History of Behavioral Sciences 4:55-61.

Hampshire, Kate 2001. The impact of male migration on fertility decisions and outcomes in northern Burkina Faso. In Soraya Tremayne (Ed.). Managing Reproductive Life: Cross-Cultural Themes in Sexuality and Fertility. (Pp. 107-125). Oxford: Berghahn Books.

Hanawalt, Barbara A. 2003. The child in the middle ages and the renaissance. In Willem Koops, and Michael Zucherman (Eds.) Beyond the Century of the Child: Cultural history and Developmental Psychology. (Pp.21-42), Philadelphia: University of Pennsylvania Press.

Hardenberg, Roland 2006. Hut of the young girls: Transition from childhood to adolescence in a middle Indian tribal society. In Deepak K. Behera (Ed.). Childhoods in South Asia. (Pp. 65-81). Singapore: Pearson Education.

Harkness Sara and Super Charles, (Eds.). 1995. Parents' Cultural Belief Systems: Their Origins, Expressions, and Consequences. New York: The Guilford Press.

Harkness, Sara, Super, Charles M. and Keefer, Constance. H. 1992. Learning to be an American parent: How cultural models gain directive force. In Roy D'Andrade and Claudia Strauss (Eds.), Human Motives and Cultural Models. pp. 163-78. Cambridge: Cambridge University Press.

Harvey, Travis A. and Buckley, Lila 2009. Childbirth in China. In Helaine Selin and Pamela K. Stone (Eds.). Childhood across Cultures: Ideas and Practices of Pregnancy, Childbirth and the Postpartum. (Pp. 55-69).

Amherst, MA: Springer.

Haxaire, Claudie 2007. Soins, toilette du nouveau-né et rite d'imposition du nom chez les Gouro de Côte d'Ivoire. 
In Doris Bonnet and Laurence Pourchez (Eds.), Du Soin au Rite dans L'infance. (Pp. 103-112). Paris: IRD.

Hearn, Kelly 2007. Ancient tomb found in Mexico reveals mass child sacrifice. National Geographic News June $12^{\text {th }}$. news.nationalgeographic.com/news/2007/06/070612-tomb-child.html

Heilbrunn (ND) Timeline of art history Metropolitan Museum of Art. www.metmuseum.org/toah/hd/azss/ho_00.5.30.htm

Helander, Bernhard 1988. The Slaughtered Camel: Coping with Fictitious Descent Among the Hubeer of Southern Somalia. Uppsala, Sweden: University of Uppsala, Department of Anthropology.

Henderson, Richard N. 1972. The King in Every Man: Evolutionary Trends in Onitsha Ibo Society and Culture. New Haven: Yale University Press.

Henrich, Joseph, Heine, Steven J. and Norenzayan, Ara (2010). The weirdest people in the world? Behavioural and Brain Sciences 33: 61-81.

Hernandez, Theodore 1941. Children among the Drysdale River Tribes. Oceania 12(2): 122-133.

Heywood, Colin 2001. A History of Childhood: Children and Childhood in the West from Medieval to Modern Times. Cambridge: Polity Press.

Hilger, M. Inez 1951. Chippewa Child Life and its Cultural Background. Washington, D.C.: US Government Print Office.

Hill, Kim, and A. Magdalena Hurtado 1996. Ache Life History: The Ecology and Demography of a Foraging People. Hawthorne, New York: Aldine de Gruyter.

Horn, Cornelia B. and Martens, John W. 2009. "Let the Little Children Come to Me:" Childhood and Children in Early Christianity. Washington, D.C.: The Catholic University Press.

Hostetler, John A. and Huntington, Gertrude E. 1971/1992. Amish Children: Education in the Family, School, and the Community. Orlando, FL: Harcourt Brace Jovanovich, 2nd edition.

Houby-Nielsen, Sanne 2000. Child burials in ancient Athens. In Joanna S. Derevenski (Ed.), Children and Material Culture. pp. 151-66. London: Routledge.

Howard, Alan 1973. Education in 'Aina Pumehana: The Hawaiian-American student as hero. In Solon T. Kimball, and Jacquette H. Burnett (Eds.), Learning and Culture. (pp. 115-129). Seattle, WA: University of Washington Press.

Howell, Nancy 1979. Demography of the Dobe !Kung. New York: Academic Press.

Howell, Signe 1988. From Child to human: Chewong concepts of self. In Jahoda, Gustav and Lewis, Ioan M. (Eds.). Acquiring Culture: Cross Cultural Studies in Child Development. (Pp. 147-168), London: Croom Helm.

Howrigan, Gail A. 1988. Fertility, infant feeding and change in Yucatan. In Robert A. LeVine, Patricial M. Miller, and Mary M. West (Eds.), Parental Behavior in Diverse Societies. New Directions for Child Development 40: $37-$ 50.

Hrdy, Sarah B. 1999. Mother Nature: Maternal Instincts and How They Shape the Human Species. New York: Ballantine.

Hrdy, Sarah B. 2006. Evolutionary context of human development: The cooperative breeding model. In C. Sue Carter, Lieselotte Ahnert, K. E. Grossmann, Sarah B. Hrdy, Michael E. Lamb, Stephen W. Porges and Norbert Sachser (Eds.), Attachment and Bonding: A New Synthesis. pp. 9-32. Cambridge, MA: MIT Press.

Irons, William 2000. Why do the Yomut raise more sons than daughters?, In Lee Cronk, Napoleon Chagnon and William Irons (Eds.), Adaptation and Human Behavior: An Anthropological Perspective. (Pp. 223-236). New York: Aldine. 
Jay, Robert R. 1969. Javanese Villagers: Social Relations in Rural Modjokuto. Cambridge, MA: MIT Press.

Jenkins, Carol L., Orr-Ewing, Alison K., and Heywood, Peter F. 1985. Cultural aspects of early childhood growth and nutrition among the Amele of Lowland Papua New Guinea. In Leslie B. Marshall (Ed.), Infant Care and Feeding in the South Pacific. Pp. 29-50. New York: Gordon and Beach Science.

Jocano, F. Landa 1969. Growing Up in a Philippine Barrio. New York: Holt, Rinehart, \& Winston.

Johnson, Michelle C. 2000. The view from the Wuro: A guide to child rearing for Fulani parents. In Judy DeLoache and Alma Gottlieb (Eds.), A World of Babies: Imagined Childcare Guides for Seven Societies. Pp. 171-98.

Cambridge: Cambridge University Press.

Kağitcibasi, Cigdem and Ataca, Bilge 2005. Value of children and family change: A three-decade portrait From Turkey. Applied Psychology: An International Review 54: 317-37.

Karen, Robert 1998. Becoming Attached: First Relationships and How They Shape Our Capacity to Love. New York: Oxford University Press.

Karplus, Yuval and Karplus, Miki 1989. Cultural variations in child caretaking practices among the Negev Bedouins: Implications for the management of developmental disabilities. Paper presented at the $4^{\text {th }}$ World Congress, WAIPAD, CH-Lugano.

Katz, Esther 2007. Rites de vie, rites de mort (enfants Mixteèques du Mexique). In Bonnet, Doris and Pourchez, Laurence (Eds) Du Soin au Rite dans L'infance. (Pp. 281-300). Paris: IRD.

Kertzer, David 1993. Sacrificed for Honor: Italian Infant Abandonment and the Politics of Reproductive Control. Boston, MA: Beacon Press.

Keshavjee, Salmaan 2006. Bleeding babies in Badakhshan: Symbolism, materialism, and the political economy of traditional medicine in Post-Soviet Tajikistan. Medical Anthropology Quarterly, 20: 72-93.

Kim, Uichol and Choi, So-Hyang 1994. Individualism, collectivism, and child development: A Korean perspective. In Patricia M. Greenfield and Rodney R. Cocking (Eds.) Cross-cultural Roots of Minority Child Development, (Pp. 227-259). Hillsdale, NJ: Lawrence Erlbaum Associates.

Kinaston, Rebecca L., Buckley, Hallie R., Halcrow, Sian E., Spriggs, Matthew J.T., Bedford, Stuart, Neal, K., Gray, A. 2009. Investigating foetal and perinatal mortality in prehistoric skeletal samples: a case study from a 3000-yearold Pacific Island cemetery site. Journal of Archaeological Science 36: 2780-2787.

Kinney, Anne B. 1995. Dyed silk: Han notions of the moral development of children. In Anne B. Kinney (Ed.), Chinese Views of Childhood. Pp. 17-56. Honolulu: University of Hawai'i Press.

Keller, Heidi 2007. Cultures of Infancy. Mahwah, NJ: Erlbaum.

King, Stacie M. 2006. The making of age in ancient coastal Oaxaca. In Traci Adren and Scott R. Hutson (Eds.), The Social Experience of Childhood in Ancient Mesoamerica. pp. 169-200. Boulder, CO: University of Colorado Press.

Klaus, Haagen, Centurion, Jorge, and Curo, Manuel 2010. Bioarchaeology of human sacrifice: Violence, identity and the evolution of ritual killing at Cerro Cerrillos, Peru. Antiquity 84:1102-22.

Kleijueqgt, Marc 2009. Ancient Mediterranean world, childhood and adolescence. In Richard A. Shweder, Thomas R. Bidell, Anne C. Dailey, Suzanne D. Dixon, Peggy J. Miller, John Modell (Eds.), The Child: An Encyclopedic Companion. pp 54-6. Chicago, IL: The University of Chicago Press.

Kojima, Hideo 2003. The History of Children and Youth in Japan. In Willem Koops, and Michael Zucherman (Eds.) Beyond the Century of the Child: Cultural history and Developmental Psychology. (Pp.112-135), Philadelphia: University of Pennsylvania Press. 
Kopp, Claire B., Khoka, Ellen W., and Sigman, Marian 1977. A comparison of sensorimotor development among infants in India and the United States. Journal of Cross-Cultural Psychology, 8(4):435-451.

Kramer, Karen L. and Greaves, Russell D. 2007. Changing patterns of infant mortality and maternal fertility among Pumé foragers and horticulturalists. American Anthropologist 109: 713-26.

Kulick, Don 1992. Language Shift and Cultural Reproduction: Socialization, Self, and Syncretism in a Papua New Guinea Village. Cambridge: Cambridge University Press.

Kulick, Don and Stroud, Christopher 1993. Conceptions and uses of literacy in a Papua New Guinean village. In Street, Brian (Ed) Cross-Cultural Approaches to Literacy. (Pp 30-61) Cambridge: Cambridge University Press.

Kuroda, Hideo 1998. A social historical view of the children of the Edo period. In Kumon Children's Research Institute (Ed.), Children Represented in Ukiyo-e, pp. 10-12. Osaka, Japan: Kumon Institute of Education.

Lancy, David F. 2007. Accounting for variability in mother-child play. American Anthropologist, 109(2): 273-284.

Lancy, David F. 2008. The Anthropology of Childhood: Cherubs, Chattel, Changelings. Cambridge: Cambridge University Press.

Lancy, David F. 2010. When nurture becomes nature: Ethnocentrism in studies of human development. Behavioral and Brain Sciences 33: 39-40.

Lancy, David F. and Grove, M. Annette 2010. Learning guided by others. In David F. Lancy, Suzanne Gaskins and John Bock (Eds.), The Anthropology of Learning in Childhood. pp. 145-79. Lanham, MD: Alta-Mira Press.

Lancy, David F. and Grove, M. Annette 2011a. "Getting Noticed": Middle childhood in cross-cultural perspective. Human Nature 22: 281-302.

Lancy, David F. and Grove, M. Annette, 2011b. Marbles and Machiavelli: The role of game play in children's social development. American Journal of Play 3: 489-99.

Langness, Louis.L. 1981. Child abuse and cultural values: the case of New Guinea In Korbin, Jill (Ed.) Child Abuse and Neglect. (Pp. 13-34). Berkeley, CA: University of California Press.

Leavitt, Stephen C. 1989. Cargo, Christ, and Nostalgia for the Dead: Themes of Intimacy and Abandonment in Bumbita Arapesh Social Experience. Unpublished Ph.D. Dissertation. San Diego, CA: University of California-San Diego.

Lebegyiv, Judit 2009. Phases of childhood in early Mycenaean Greece. Childhood in the Past 2: 15-32.

Lebra, Takie S. 1994. Mother and child in Japanese socialization: A Japan-U.S. comparison. In Patricia M.

Greenfield and Rodney R. Cocking (eds.) Cross-cultural Roots of Minority Child Development, (Pp. 259-274).

Hillsdale, NJ: Lawrence Erlbaum Associates.

Lee, K. Alexandra 1994. Attitudes and prejudices towards infanticide: Carthage, Rome and today. Archaeological Review from Cambridge, 13, 65-79.

Leighton, Dorothea and Kluckhohn, Clyde C. 1948. Children of the People. Cambridge, MA: Harvard University Press.

Leis, Nancy B. 1982. The not-so-supernatural power of Ijaw children. In Simon Ottenberg (Ed.), African Religious Groups and Beliefs. pp. 150-69. Meerut, India: Archana.

Le Mort, Francis 2008. Infant burials in pre-pottery neolithic Cyprus: Evidence from Khiroitia. In Krum Bacvarov (Ed.), Babies Reborn: Infant/Child Burials in Pre-and Protohistory. pp. 23-32. BAR International Series 1832. Oxford: Archaeopress. 
Lepowsky, Maria A. 1987. Food taboos and child survival: A case study from the Coral Sea. In Nancy ScheperHughes, (Ed.), Child Survival: Anthropological Perspectives on the Treatment and Maltreatment of Children. (Pp 71-92). Dordrecht, The Netherlands: D. Reidel Publishing.

Lessa, William A. 1966. Ulithi: A Micronesian Design For Living. San Francisco, CA: Holt, Rinehart, and Winston.

LeVine, Robert A. 2004. Challenging expert knowledge: Findings from an African study of infant care and development. In Uwe P. Gielen and Jaipaul Roopnarine (Eds). Childhood and Adolescence: Cross-Cultural Perspectives and Applications. pp. 149-65. Westport, CT: Praeger.

LeVine, Robert A. 2007. Ethnographic studies of childhood: A historical overview. American Anthropologist 109: $247-60$.

LeVine, Robert and Norman, Karin 2001. The infant's acquisition of culture: Early attachment reexamined in anthropological perspective. In Carmella C. Moore and Holly F. Matthews (Eds.), The Psychology of Cultural Experience. pp. 83-104. Cambridge: Cambridge University Press.

LeVine, Sarah, LeVine, Robert A. 1981. Child abuse and neglect in sub-Saharan Africa. In Jill Korbin (Ed.), Child Abuse and Neglect: Cross-Cultural Perspectives. pp. 35-55. Berkeley, CA: University of California Press.

Lewis, Mary E. 2007. The Bioarchaeology of Children: Perspectives from Biological and Forensic Anthropology. Cambridge: Cambridge University Press.

Liamputtong, Prancee 2009. Nyob Nruab Hlis: Thirty days confinement in Hmong culture. In Helaine Selin and Pamela K. Stone (Eds.). Childhood across Cultures: Ideas and Practices of Pregnancy, Childbirth and the Postpartum. (Pp. 161-173). Amherst, MA: Springer.

Little, Christopher A. J. L. 2008. Becoming an Asabano: The Socialization of Asabano Children, Duranmin, West Sepik Province, Papua New Guinea. Unpublished Master's Thesis. Trent University. Peterborough, ON, Canada.

Loeb, Edwin M. 1962. Shaman and seer. American Anthropologist. 31: 60-84.

Mabilia, Mara 2000. The cultural context of childhood diarrhea among Gogo infants. Anthropology and Medicine, 7: 191-208.

Maclean, Una. 1994. Folk medicine and fertility: Aspects of Yoruba medical practice affecting women. In Carol P. MacCormack (Ed.), Ethnography of Fertility and Birh., pp. 151-69. Prospect Heights, IL: Waveland Press, Inc.

MacGinnis, John 2011. Aspects of child labour and the status of children in Mesopotamia in the first millennium BC. Paper given at Fourth Annual Society for the Study of Childhood in the Past Conference, Cambridge October $1^{\text {st }}$

Maiden, Annet H. and Farwell, Edie 1997. The Tibetan Art of Parenting. Boston, MA: Wisdom.

Mangin, Eugène B. 1921. Essay on the Manners and Customs of the Mossi People in the Western Sudan. Paris: Augustin Challamel.

Martin, Diana 2001. The meaning of children in Hong Kong. In Soraya Tremayne (Ed.), Managing Reproductive Life: Cross-Cultural Themes in Sexuality and Fertility. pp. 157-71. Oxford: Berghahn Books.

McGilvray, Dennis B. 1994. Sexual power and fertility in Sri Lanka: Batticaloa Tamils and Moors. In Carol P. MacCormack (Ed.) Ethnography of Fertility and Birth. (Pp.15-63) Prospect Heights, IL: Waveland Press, Inc.

Meehan, Courtney L. 2009. Maternal time allocation in two cooperative childrearing societies. Human Nature, 20: 375-393.

Meskell, Lynn 1994. Dying young: The experience of death at Deir el Medina. Archaeological Review from Cambridge 13: 35-45. 
Middleton, John 1965. The Lugbara of Uganda. New York: Holt, Rinehart and Winston Inc.

Miller, Barbara 1987. Female infanticide and child neglect in rural North India. In Nancy Scheper-Huges (Ed.), Child Survival, (Pp. 95-112). Dordrecht, Holland: D. Reidel Publishing Company.

Mintz, Steven 2004. Huck's Raft: A History of American Childhood. Cambridge, MA: Belknap Press.

Montague, Susan P. 1985. Infant feeding and health care in Kaduwaga Village, the Trobriand Islands. In Marshall, Leslie B. (Ed.), Infant Care and Feeding in the South Pacific. Pp. 83-96. New York: Gordon and Beach Science.

Morel, Marie-France 2007. Histoire du maillot en Europe occidental. In Bonnet, Doris and Pourchez, Laurence (Eds) Du Soin au Rite dans L'infance. (Pp. 62-84), Paris: IRD.

Morgan, Lynn M. 1998. Ambiguities lost: Fashioning the fetus into a child in Ecuador and the United States. In Nancy Scheper-Hughes and Carolyn Sargent (Eds.), Small Wars: The Cultural Politics of Childhood. pp. 58-74. Berkeley, CA: University of California Press.

Morton, Helen 1996. Becoming Tongan: An Ethnography of Childhood. Honolulu: University of Hawai'i Press.

Moses, Sharon 2008. Çatalhöyük's Foundation Burials: Ritual Sacrifice or Convenient Deaths? In Krum Bacvarov (Ed.), Babies Reborn: Infant/Child Burials in Pre-and Protohistory. pp. 45-52. BAR International Series 1832. Oxford: Archaeopress.

Mull, Dorothy S. and Mull, J. Dennis 1987. Infanticide among the Tarahumara of the Mexican Sierra Madre. In Nancy Scheper-Hughes (Ed.), Child Survival: Anthropological Perspectives on the Treatment and Maltreatment of Children. (Pp. 113-132). Dordrecht, The Netherlands: D. Reidel Publishing Company.

Murphy, Yolanda and Murphy, Robert F. 1985. Women of the Forest. New York: Columbia University Press.

Musharbash, Yasmine 2011. Warungka: Becoming and unbecoming a Warlpiri person. In Ute Eickelkamp (Ed.), Growing Up in Central Australia: New Anthropological Studies of Aboriginal Childhood and Adolescence. Pp. 6381. Oxford: Berghahn Books.

Nath, Y. V. Surendra 1960. Bhils of Ratanmal: An analysis of the social structure of a western Indian community. The M.S. University Sociological Monograph Series I. Baroda, India: Maharaja Sayajirao University of Baroda.

Ndege, George O. 2007. Culture and Customs of Mozambique. Westport, CT. Greenwood Press.

Newton, Ruth and Schore, Allan 2008. The Attachment Connection: Parenting a Secure and Confident Child Using the Science of Attachment Theory. Oakland, CA: New Harbinger Publications.

Nichter, Mimi and Nichter, Mark 1987. A tale of Simeon: Reflections on raising a child while constructing fieldwork in rural South India. In, Joan Cassell (Ed.) Children in the Field: Anthropological Experiences. (Pp. 6589). Philadelphia, PA: Temple University Press.

Nicolaisen, Ida 1988. Concepts and learning among the Punan Bah of Sarawak. In Gustav Jahoda and Ioan M. Lewis (Eds.), Acquiring Culture: Cross Cultural Studies in Child Development. pp. 193-221. London: Croom Helm.

Nimmo, H. Arlo 1970. Bajau sex and reproduction. Ethnology, 9: 251-262.

Ochs, Elinor and Schieffelin, Bambi B. 1984. Language acquisition and socialization: Three developmental stories and their implications. In Richard Shweder and Robert L. LeVine (Eds.), Culture Theory: Essays on Mind, Self, and Society. pp. 276-320. Cambridge: Cambridge University Press.

Orme, Nicholas 2003. Medieval Children. New Haven, CT: Yale University Press.

Paradise, Ruth 1996. Passivity or tacit collaboration: Mazahua interaction in cultural context. Learning and Instruction 6: 379-89. 
Pearsall, Marion 1950. Klamath Childhood and Education. Berkeley, CA: University of California Press.

Picchi, Debra. 2000. The Bakairí Indians of Brazil: Politics, Ecology, and Change. Prospects Heights, Ill.: Waveland Press.

Platt, Katherine 1988. Cognitive development and sex roles of the Kerkennah Islands of Tunisia. In Gustav Jahoda, and Ioan M. Lewis (Eds.). Acquiring Culture: Cross Cultural Studies in Child Development. (Pp. 271-287), London: Croom Helm.

Pomponio, Alice 1992. Seagulls Don't Fly Into The Bush. Belmont, CA: Wadsworth.

Pourchez, Laurence 2007. Les transformations du corps de l'enfant: façonnage du visage et bandage du tronc de le'infant à l'île de la Réunion. In Bonnet, Doris and Pourchez, Laurence (Eds), Du Soin au Rite dans L'infance. (Pp. 43-59), Paris: IRD.

Rao, Aparna 1998. Autonomy: Life Cycle, Gender, and Status among Himalayan Pastoralists. Oxford: Berghahn Books.

Rattray, Robert S. 1927. Religion and Art in Ashanti. Oxford: Clarendon Press.

Rawson, Beryl 2003. Children and Childhood in Roman Italy. Oxford: Oxford University Press.

Razy, Élodie 2007. Naître Et Devenir: Anthropologie De La Petite Enfance En Pays Soninké, Mali. (Birth and Becoming: The Anthropology of Infancy in Soninké, Mali) Nanterre, France: Société D'ethnologie,

Read, Margaret 1960. Children of Their Fathers. New Haven, CT: Yale University Press.

Rega, Elizabeth 1997. Age, gender and biological reality in the Early Bronze Age cemetery at Morkrin. In Jenny Moore and Eleanor Scott (Eds.), Invisible People and Processes. (Pp. 229-247). London, UK: Leicester University Press.

Reichel-Dolmatoff, Gerardo 1976. Training for the priesthood among the Kogi of Columbia, In Johannes Wilbert (Ed.), Enculturation in Latin America. pp. 265-88. Los Angeles: UCLA Latin American Center Publications.

Remorini, Carolina 2011. Becoming a person from the Mbya Guarani perspective: A brief comment. Paper presented at Symposium: "The Cultural Construction of Identity: How Children Become Persons" Third Annual Conference AAA Childhood/Youth Interest Group, Las Vegas, NV, Feb $23^{\text {rd }}$

Reynolds, Pamela 1991. Dance Civet Cat: Child Labour in the Zambezi Valley. Athens, OH: Ohio University Press.

Riches, David 1974. The Netsilik Eskimo: A special case of selective female infanticide. Ethnology, 13:351-361.

Riesman, Paul 1992. First Find Yourself a Good Mother. New Brunswick, N.J.: Rutgers

University Press,

Rival, Laura 1998. Androgynous parents and guest children: The Huaorani Couvade. The Journal of the Royal Anthropological Institute, 4:619-642.

Roach, John 2010. "Chilling" child sacrifices found at prehistoric site. National Geographic News December $23^{\text {rd }}$ Available: http://news.nationalgeographic.com/news/2010/12/101223-child-sacrifices-bloodletting-archaeologyscience/

Rochat, Phillipe 2009. Others in Mind: Social Origins of Self-Consciousness. Cambridge: Cambridge University Press.

Roscoe, John 1924. The Bagesu and Other Tribes of the Uganda Protectorate. Cambridge. Cambridge University Press. 
Sachs, Dana, and Vu, Le Quang 2005. Vietnam unearths its royal past. National Geographic Magazine Interactive Edition June.

http://ngm.nationalgeographic.com/ngm/0506/resources geo.html?fs=seabed.nationalgeographic.com\#bibliography

Sargent, Carolyn F. 1988. Witchcraft and infanticide in Bariba culture. Ethnology 27(1):79- 95.

Scheer, Jessica and Groce, Nora 1988. Impairment as a human constant: Cross-cultural and historical perspectives on variation. Journal of Social Issues 44: 23-37.

Scheper-Hughes, Nancy, 1987. "Basic Strangeness": Maternal estrangement and Infant death: A critique of bonding theory. In Charles Super (Ed.), The Role of Culture in Developmental Disorder. Pp. 131-51. New York: Academic Press Inc.

Schiefenhovel, Wulf. 1989. Reproduction and sex-ratio manipulation through preferential female infanticide among the Eipo, in the Highlands of Western New Guinea. In Anne E. Rasa, Christian Vogel and Eckart Voland (Eds.), The Sociobiology of Sexual and Reproductive Strategies. pp. 170-93. New York: Chapman and Hall.

Scott, Eleanor 1999. The Archaeology of Infancy and Infant Death. Oxford: Archaeopress.

Sear, Rebecca and Mace, Ruth 2008. Who keeps children alive? A review of the effects of kin on child survival. Evolution and Human Behavior 29: 1-18.

Sellen, Daniel W. 1998. Infant and young child feeding practices among African pastoralists: The Datoga of Tanzania. Journal of Biosocial Science 3: 481-499.

Senior, Louise M. 1994. Babes in the 'hood: Concepts of personhood and the spatial segregation of infants from adults in archaeological burial practices. Paper presented at the $59^{\text {th }}$ annual meeting of the Society for American Archaeology, Anaheim, CA. April $22^{\text {nd }}$.

Sharer, Robert J. 1994. The Ancient Maya. Fifth edition. Stanford: Stanford University Press.

Shein, Max 1992. The Precolumbian Child. Culver City, CA: Labyrinthos.

Shostak, Marjorie 1981. Nisa: The Life and Words of a !Kung Woman. Cambridge, MA: Harvard University Press.

Sillar, Bill 1994. Playing with God: Cultural perceptions of children, play, and miniatures in the Andes.

Archaeological Review from Cambridge 13: 47-63

Smith, Patricia and Kahila, Gila 1992. Identification of infanticide in archeological sites: A case study from the Late Roman-Early Byzantine periods at Ashkelon, Israel. Journal of Archeological Science, 19: 667-675.

Spielmann, Katherine A. 1989. Dietary restrictions on hunter-gatherer women and the implications for fertility and infant mortality. Human Ecology 17: 321-45.

Spitz, René A. 1945. Hospitalism-An inquiry into the genesis of psychiatric conditions in early childhood. Psychoanalytic Study of the Child, 1: 53-74.

Sprott, Julie W. 2002. Raising Young Children in an Alaskan Iñupiaq Village: The Family, Cultural and Village Environment of Rearing. Westport, CT: Bergin and Garvey.

Stager, Lawrence E. and Greene, Joseph A. 2000. Were living children sacrificed to the gods? Archeology Odyssey, 3(6): $29,31$.

Stasch, Rupert 2009. Society of Others: Kinship and Mourning in a West Papuan Place. Berkeley, CA: University of California Press.

Strassmann, Beverly I. 1997. Polygyny as a risk factor for child mortality among the Dogon. Current Anthropology 38: 688-95. 
Stearman, Allyn M. 1989. Yuqui: Forest Nomads in a Changing World. New York: Holt, Rinehart, and Winston.

Stearns, Peter N. 2010. Defining happy childhoods: Assessing a recent change. Journal of the History of Childhood and Youth,3: 165-86.

Steiner, Leslie M. 2007. Mommy Wars: Stay-at-Home and Career Moms Face Off on the Choices, Their Lives, Their Families. New York: Random House.

Stoller, Paul 1989. Fusion of the Worlds: An Ethnography of Possession among the Songhay of Niger. Chicago, IL: University of Chicago Press.

Sussman, George. 1982. Selling Mother's Milk: The Wet-Nursing Business in France, 1715-1914. Urbana, IL: University of Illinois Press.

Teixeira, Maria 2007. Parachever l'humanité toilette, massage et soins des enfants Manjak (Guinée-Bissau, Sénégal). In Doris Bonnet and Laurence Pourchez (Eds.), Du Soin au Rite dans L'infance. pp . 129-45. Paris: IRD.

Telban, Borut 1997. Being and 'non-being' in Ambonwari (Papua New Guinea) ritual. Oceania 67: 308-25.

Tiberio of Assisi 1510. Madonna de Soccorso (Our Lady of Suceor) Painting in Chiese. San Francesco: Montefaleo, IT

Tiesler, Vera 2011. Becoming Maya: Infancy and upbringing through the lens of Pre-Hispanic head shaping. Childhood in the Past 4: 117-132.

Tizard, Jack and Tizard, Barbara 1974. The institution as an environment for development. In Martin P.M. Richards (Ed.), The Integration of a Child Into a Social World. (Pp. 137-152). Cambridge: Cambridge University Press.

Tjitayi, Katrina and Lewis, Sandra 2011. Envisioning lives at Ernabella. In Ute Eickelkamp (Ed.), Growing up in Central Australia: New Anthropological Studies of Aboriginal Childhood and Adolescence. Pp. 49-62. Oxford: Berghahn Books.

Tomlinson, Mark, Murray, Lynne, and Cooper, Peter 2010. Attachment Theory, culture, and Africa: Past, present, and future. In Phyllis Erdmand and Kok-mun Ng (Eds.), Attachment: Expanding the Cultural Connections. pp. 181209. New York: Routledge.

Trivers, Robert L. 1972. Parental investment and sexual selection. In Bernard Campbell (Ed.), Sexual Selection and the Descent of Man. Pp. 136-79. Chicago: Aldine Publishing Company.

Tronick, Edward Z., Thomas, R. Brook, and Daltabuit, Magali 1994. The Quechua manta pouch: A caretaking practice for buffering the Peruvian infant against the multiple stressors of high altitude. Child Development 65: 1005-13.

True, Mary M., Pisani, Leila, and Oumar, Fadimata 2001. Infant-mother attachment among the Dogon of Mali. Child Development 72: 1451-66.

Tulloch, Marian I. 2004. Parental fear of crime: A discursive analysis. Journal of Sociology 40: 362-77.

van Ijzendoorn, Marinus H., and Sagi-Schwartz, Abraham 2008. Cross-cultural patterns of attachment: Universal and contextual dimensions. In Jude Cassidy and Phillip R. Shaver (Eds.), Handbook of Attachment: Theory, Research and Clinical Applications. (Pp. 713 - 734). New York: Guilford Press.

Viccars, John D. 1949. Witchcraft in Bolobo, Belgian Congo. Africa 19(3): 220-29.

Wagley, Charles 1977. Welcome of Tears: The Tapirapé Indians of Central Brazil. New York; Oxford University Press.

Wee, Vivienne 1992. Children, population policy, and the state in Singapore. In Sharon Stephens (Ed), Children and the Politics of Culture. Pp. 184-217. Princeton, NJ: Princeton University Press, 
Weisner, Thomas S. and Gallimore, Ronald 1977. My brother's keeper: Child and sibling caretaking. Current Anthropology 18: 169-90.

Whittemore, Robert D. 1989. Child Caregiving and Socialization to the Mandinka Way: Toward an Ethnography of Childhood. Unpublished PhD dissertation. University of California, Los Angeles.

Wiedemann, Thomas 1989. Adults and Children in the Roman Empire. New Haven: Yale University Press.

Wileman, Julie 2005. Hide and Seek: The Archaeology of Childhood. Glouscstershire, UK: Tempus Publishing Limited.

Wiley, Andrea S. 2004. An Ecology of High-Altitude Infancy. Cambridge: Cambridge University Press.

Wolf, Margery 1972. Women and the Family in Rural Taiwan. Stanford, CA.: Stanford University Press.

Woolf, Alex 1997. At home in the long Iron Age: A dialogue between households and individuals in cultural reproduction. In Jenny Moore and Eleanor Scott (Eds.), Invisible People and Processes. pp. 68-78. London, UK: Leicester University Press.

Yanagisawa, Satoko 2009. Childbirth in Japan. In Helaine Selin and Pamela K. Stone (Eds.), Childhood Across Cultures: Ideas and Practices of Pregnancy, Childbirth and the Postpartum. Pp. 85-94. Amherst, MA: Springer.

Zeitlin, Marian 1996. My child Is my crown: Yoruba parental theories and practices in early childhood. In Sara Harkness and Charles M. Supe (Eds.) Parent's Cultural Belief Systems: Their Origins, Expressions, and Consequences. (Pp. 407-427), New York: Guilford Press.

Zelizer, Viviana A. 1985. Pricing the Priceless Child: the Changing Social Value of Children. New York: Basic Books.

\footnotetext{
${ }^{1}$ I am grateful to Amanda Davis Arthur, Tanya Collings, James Young, M. Annette Grove and Elizabeth Payne for their contributions to this research project. Annette Grove also assisted with editing. I thank Editors Keller and Otto for their helpful critique of an earlier draft and Suzanne Gaskins for her valuable feedback.

${ }^{2}$ www.attachmentparenting.org/

${ }^{3}$ www.attachment.org/

${ }^{4}$ online.wsj.com/article/SB10001424052748704462704575590603553674296.html?KEYWORDS=erica+jong Another variation in the intensive mothering movement is the "naturalist" approach which has also attracted the attention of social critics (Badinter 2012)

${ }^{5}$ I must stress that this level of conflict within families is by no means universal or even widespread. On the contrary, I have to agree with Hrdy's (2006) characterization of humans as cooperative breeders, a corollary of which is that immediate and extended family members do contribute in positive ways to the child's survival, including co-wives. A key factor differentiating among these cases is the closeness of kin ties. In situations of chronic family conflict, the household consists of a mixture of people who aren't all closely related. The women are living patrilocally, with little contact with their natal families and/or the child may be exposed to the questionable care of step-family members.

${ }^{6}$ Anecdotally, cowives are described as assisting each other with domestic duties, including childcare. However, the only studies to attempt to document a positive effect on child outcomes in a polygynous household found such effects only for high-ranking wives with negative outcomes for the children of low-ranking wives (Lancy 2008: 126).
} 